\title{
Morphology and sedimentary architecture of a modern volcaniclastic turbidite system: The Cilaos fan, offshore La Réunion Island
}

\author{
Emmanuelle Sisavath ${ }^{a, b}{ }^{b}{ }^{*}$, Nathalie Babonneau ${ }^{c}$, Francky Saint-Ange $^{d}$, Patrick Bachèlery ${ }^{a}$, \\ Stephan J. Jorry ${ }^{b}$, Christine Deplus ${ }^{\mathrm{e}}$, Béatrice De Voogd ${ }^{f}$, Bruno Savoye ${ }^{\mathrm{b}}$
}

\footnotetext{
a Laboratoire GéoSciences Réunion, Université de la Réunion, Institut de Physique du Globe de Paris CNRS, UMR7154, 15 avenue René Cassin, BP 7151. 97715 Saint Denis messag Cedex 9, La Réunion, France

${ }^{\mathrm{b}}$ IFREMER, Géosciences Marines, Laboratoire Environnements Sédimentaires, BP70, 29280 Plouzané, France

${ }^{\mathrm{c}}$ Université de Brest, IUEM, UMR CNRS 6538, Brest, France

d Geological Survey of Canada (Atlantic), Bedford Institute of Oceanography, P.O. Box 1006, Dartmouth, Nova Scotia, Canada B2Y 4A2

e Institut de Physique du Globe de Paris et CNRS, UMR 7154, 1, rue Jussieu, 75238 Paris Cedex 05, France

${ }^{f}$ Université de Pau et des pays de l'Adour CNRS, UMR 5212, 64000 Pau, France

*: Corresponding author : Emmanuelle Sisavath, Tel.: + 332290085 65; fax: + 33298224570 . ;

email address : emmanuelle.sisavath@ifremer.fr
}

\begin{abstract}
:
Recent oceanographic surveys revealed the existence of five volcaniclastic deep-sea fans off La Réunion Island. The Cilaos fan is a large volcaniclastic submarine fan, connected to rivers that episodically experience torrential floods through a narrow and steep shelfï slope system. New piston cores presented in this study together with echosounder profiles give new insight into the evolution of this extensive and sand-rich turbidite system. The Cilaos fan extends over $15,000 \mathrm{~km}^{2}$ on an abyssal plain and is compartmentalized by topographic highs. Located southwest of the island, the sedimentary system consists of a canyon area and a deep sea fan divided into a proximal and a distal fan. The proximal fan is characterized by its wide extent and coarse-grained turbidites. The distal fan is characterized by elongated structures and fine-grained turbidites. A detailed morphological study of the fan which includes the analysis of swath bathymetry, backscatter, echosounder, and piston core data shows that the Cilaos fan is a complex volcaniclastic deep-sea fan, highly influenced by preexisting seafloor irregularities. The canyons and the slope area show a complex and evolving sediment feeding system with a direct sediment input by the river and irregular sediment supply by submarine landslide. Three main construction stages are identified for this system: (1) an old incision phase of the channels forming wide turbidites extending over the entire distal fan; (2) a period of no or low activity characterized by a thick layer of hemipelagic mud; and (3) a local reactivation of the channel in the proximal fan. Each stage seems to be linked to a different sediment source with a progressively increasing contribution of hemipelagic sediment and mud in younger stages.
\end{abstract}

\section{Highlights}

3 We examine the architecture and morphology of a volcaniclastic fan off La Réunion. 3 Three parts compose the turbidite system: a canyon area, a proximal and a distal fan. 3 Three construction stages are identified for this volcaniclastic turbidite system. 3 These stages appear to be linked to major changes of the depositional processes

Keywords : turbidite ; deep-sea fan ; volcaniclastic ; La Reunion Island 


\section{Introduction}

Volcanic islands are subject to numerous studies on their construction or structural evolution as well as their eruptive activity, but few studies focus on the submarine part of these edifices. The knowledge of processes affecting the submarine slope of these volcanoes including the surrounding basin is an essential step for a better understanding of sediment transfer toward the seafloor, and to constrain the overall evolution of these geodynamic systems.

Mass wasting processes are an inherent part of volcanic islands with specific characteristics depending on the geodynamic setting, the sediment supply, slope angle, and climate. They are now largely considered as a major process in the evolution of such islands, significantly contributing to the edification of submarine slopes ( [Moore et al., 1989], [Deplus et al., 2001], [Masson et al., 2002], [Le Friant et al., 2004] and [Oehler et al., 2008]). Increase in resolution of marine geophysical data (swath bathymetry, echosounder and seismic data) have contributed to improve our knowledge of volcaniclastic systems at the base of volcanic slopes ( [Deplus et al., 2001], [Deplus et al., 2009], [Bosman et al., 2009] and [Casalbore et al., 2010]) and to document the occurrence of several gravity related processes, including turbidite systems.

Recent oceanographic cruises over submarine flanks of La Réunion Island and the surrounding oceanic plate led to the discovery of several volcaniclastic turbidite systems extending to more than $200 \mathrm{~km}$ from the island ( [Saint-Ange, 2009] and [Sisavath et al., 2009]). The existence of volcaniclastic turbidite off a volcanic island is not specific to La Réunion Island. Other examples are Hawaii (Garcia and Hull, 1994) and Canary Islands (Acosta et al., 2003) where volcaniclastic turbidite are visible more than $400 \mathrm{~km}$ from these islands. Volcaniclastic systems in a subduction context can also be considered such as Stromboli Island (Romagnoli et al., 2009) and Lesser Antilles Arc ( [Deplus et al., 2001] and [Le Friant et al., 2009]) where recent studies showed detailed morphology of the submarine slopes. All these systems are located in deep marine sedimentary basins surrounded volcanic islands. They show morphological structures like canyons, channels or sediment-waves ( [Wynn et al., 2000] and [Casalbore et al., 2010]), but no extensive channel lobe systems are observed, as in offshore La Réunion Island. 
No study has yet assessed a whole modern turbidite volcaniclastic system, however such a study would include a detailed examination of the sedimentary architecture and characterization of the sediment source. Our paper focuses on the study of the largest volcaniclastic turbidite system around La Réunion Island: the Cilaos deep-sea fan, located southwest of the island. It is the first documented example of a very extensive fan (with channel and lobes) originating from a volcanic island. The Cilaos turbidite system, was first described by Saint-Ange et al. (2011) and the new high-resolution dataset (swath-bathymetry backscatter and echosounder data) and sediment cores presented in this paper illustrate a complex organization of sedimentary bodies and structures from the canyon to the distal part of the turbidite fan.

This study not only provides an opportunity to investigate a modern volcaniclastic turbidite system but also to study the sedimentary processes which are involved in the development of this type of depositional deep-sea system. A large data set was examined in order to do a detailed investigation of seafloor morphology, superficial sediment distribution and recent evolution of the Cilaos deep-sea fan.

\section{Regional setting}

\subsection{Geological setting of La Réunion}

La Réunion Island is the emerged part of an intraplate volcanic system located in the western part of the Indian Ocean ( $\left.21^{\circ} \mathrm{S}, 55^{\circ} \mathrm{E}\right)$, about $750 \mathrm{~km}$ east of Madagascar (Fig. 1). La Réunion is commonly considered as the recent expression of the hotspot which formed the Deccan Traps (65 Ma ago) and subsequently the Mascarene Plateau and Mauritius Island (Bonneville et al., 1988; Duncan et al., 1989; Morgan, 1981). It could be one of the seven (or ten) main deep mantle plumes on Earth (Courtillot et al., 2003). La Réunion Island is located in the Mascarene Basin, on a compartment of oceanic lithosphere bordered by two fracture zones (FZ) separated by $350 \mathrm{~km}$ : the Mahanoro FZ to the west and Mauritius FZ to the east (Fig. 1).

The subaerial island accounts for only three percent of the whole edifice (De Voogd et al., 1999), and reaches a height of $3070 \mathrm{~m}$ above sea level. The submerged base of the volcanic edifice is 4,200 meters below sea level (mbsl), such that the total relief of the edifice is $\sim 7$ $\mathrm{km}$. The morphology of the island is dominated by two basaltic shield-volcanoes. The Piton des Neiges volcano occupies the northwestern part of the island (Fig. 1). It started to grow during the Pliocene, more than 2.1 Ma ago, and has been inactive in the last 0.012 Ma (Deniel et al., 1992; McDougall, 1971; Quidelleur et al., 2010). The main and most original feature of 
100 Piton des Neiges is the existence of three major erosional depressions, called "cirques", opened in the center of the volcano (Fig. 1). The “cirques” are partly filled by unconsolidated detritic rocks like volcanic debris avalanche deposits, debris flow deposits and other breccia (Arnaud, 2005; Bret et al., 2003; Fèvre, 2005; Oehler et al., 2005). The Piton de la Fournaise volcano (2632 $\mathrm{m}$ high) is a highly active volcanic shield. Activity at Piton de la Fournaise started less than 0.6 Ma ago (Gillot and Nativel, 1989). Eruptive activity is mainly composed of basaltic lava flows and fountains, or moderate rhythmic explosions at the vent. More explosive activity is rare, typically associated with phreatic or phreatomagmatic eruptions generated at the Dolomieu summit crater or near the coast. The frequent historic volcanic activity of Piton de la Fournaise is described by Bachelery et al. (1983), Lenat et al. (2009), Michon and Saint-Ange (2008), Peltier et al. (2008, 2009) and Stieltjes and Moutou (1988). The existence of an older and largely dismantled edifice, Les Alizés volcano, predating Piton de la Fournaise volcano, is proposed from geophysical studies (Gailler et al., 2009; Malengreau et al., 1999; Rousset et al., 1989) and drill hole data (Rancon et al., 1989). An age of 3.3 Ma was recently obtained on a sample dredged on the NE flank of Piton de la Fournaise (Smietana et al., 2010).

116 Four submarine bulges were described to the east, north, west, and south submarine flanks of La Réunion Island. Lénat and Labazuy (1990) then Oehler et al. (2004) propose that the submarine flanks of La Réunion Island are mostly built by accumulation of debris avalanche deposits: the superposition and/or juxtaposition of such deposits leading to the formation of the bulges. A recent study (Le Friant et al., 2011) proposed that the chaotic deposits on the submarine flanks of Piton des Neiges come from slow deformations such as sliding or spreading, rather than flank collapse. These slow processes lead to secondary submarine slope instability and in some cases they have triggered unconfined turbidity flows (Le Friant et al. 2011). A study of the recent submarine sedimentation off Piton de la Fournaise Volcano revealed coarse-grained turbidites and sandy lobes, confirming the presence of turbidity currents (Ollier et al., 1998).

\section{2.2. Hydrogeological settings and climate}

128 La Réunion Island is located in the subtropical zone where the climate is characterized by two seasons: a hot and wet season during the austral summer; and a cooler and dryer season

130 during the austral winter. Trade winds from the east induce highly variable precipitation regimes in time and space, with a wet windward side (east) and a dry leeward side (west). Rainfalls also vary according to elevation, with a maximum rainfall at mid-slope. Rainfall 
133 intensities are high with up to $1825 \mathrm{~mm}$ for daily precipitation amounts and up to 12,000 $\mathrm{mm}$

134 for yearly precipitation amounts (Barcelo et al., 1997; Robert, 2001).

135 On La Réunion, high erosion rates are caused by the wet tropical climate and are amplified by seasonal cyclonic conditions (Louvat and Allegre, 1997; Rad et al., 2007). Hurricanes induce rainfalls and torrential floods, causing land erosion and highly concentrated sediment loads in

138 the main river mouths (Bret et al., 2003; Fèvre, 2005; Garcin et al., 2005; Saint-Ange, 2009).

139 Recent studies (Louvat and Allegre, 1997) underline the particularities of the erosion of

140 basaltic terrains: incision rates are close to those estimated in active orogenic areas, with 141 values ranging between $0.47-3.4 \mathrm{~m} \cdot \mathrm{kyr}^{-1}$ for La Réunion Island. These high erosion rates 142 result in a dense hydrographic network with more than 750 gullies and rivers on the island, 143 only twenty of them are perennial. Five main rivers incise the slopes of the volcanoes creating 144 deep valleys (Fig. 1).

145 The transition between the subaerial and the submarine environments is characterized by a 146 narrow shelf that is locally absent especially around the Piton de la Fournaise (Fig. 2). The 147 local absence of the shelf and the presence of steep submarine slopes around the island favour 148 a rapid transfer of sediment from the coast toward the submarine slopes of the volcanic 149 edifice and on to the abyssal plain.

150 One of the major rivers of the Island is the Rivière Saint-Etienne, whose headwaters reach 151 altitudes of 3000 m (Fig. 1). The Rivière Saint-Etienne has a drainage basin of about $360 \mathrm{~km}^{2}$ 152 (Figs. 1 and 2) composed of two main tributaries: the "Bras de Cilaos" and the "Bras de la 153 plaine". The "Bras de Cilaos" drains the inner part of the cirque while the "Bras de la Plaine" 154 comes from the outer slopes of the cirque. They merge $6 \mathrm{~km}$ from the coast to form the 155 Rivière Saint-Etienne. The basement lithology in the drainage basin is dominated by coarse156 grained sediments ranging from sand to boulders (Saint-Ange et al, 2011). The mean fluvial 157 solid load of the Rivière Saint-Etienne is estimated around $470000 \mathrm{~m}^{3} / \mathrm{yr}$ and during 158 important floods it reaches 1-2 million $\mathrm{m}^{3} / \mathrm{yr}$ (SOGREAH, 1998).

159 3. Data and methods

160 The dataset used in this paper was collected during the recent oceanographic cruises 161 FOREVER in April 2006 onboard the RV L'Atalante, ERODER 1 in July 2006 onboard the 162 BHO Beautemps-Beaupré, and ERODER 2 in January 2008 onboard the RV Meteor (Fig. $1632 \mathrm{~A})$. 
164 During the FOREVER survey, the lower submarine slopes of La Réunion volcanic edifice 165 and the surrounding oceanic plate were imaged using a hull-mounted Simrad EM12 Dual multibeam echo-sounder system (frequency $12 \mathrm{kHz}, 162$ beams with $1.8^{\circ} \times 3.5^{\circ}$ angular resolution, Fig. 2A). The coverage extends from the fracture zones to $300 \mathrm{~km}$ south of the island. $3.5 \mathrm{kHz}$ echosounder and seismic reflection data were acquired along 12,200 km of profiles. Two Kullenberg piston cores were also successfully collected in the Cilaos deep-sea fan.

Cruise ERODER 1 (Fig. 2A) complemented the preexisting swath bathymetry and backscatter data on the upper submarine slopes of the volcanic edifice. It aimed to establish the link between the onshore morphological structures and the deep-marine morphology. Data were collected using a hull-mounted Kongsberg Simrad EM120 system (frequency 12 kHz, 192 beams with $1^{\circ} \times 1^{\circ}$ angular resolution). Two Kullenberg piston cores were successfully collected in the study area.

Cruise ERODER 2 (Fig. 2A) was mainly devoted to coring the sedimentary systems. Twelve piston cores, with a diameter of $125 \mathrm{~mm}$, were collected using a Kullenberg type piston corer. A total of eight cores are located in the Cilaos deep-sea fan. In addition, more detailed swath bathymetry and backscatter data (Kongsberg Simrad EM120 system) and echosounder data (Parasound system) were collected over the Cilaos fan. The coverage was also extended further south.

Results shown in this paper are mainly based on the analysis of swath bathymetry, backscatter data, Parasound and $3.5 \mathrm{kHz}$ echosounder profiles, and sedimentological study of piston cores. The bathymetry and the sonar backscatter image of cruises ERODER 1 and ERODER2 were processed at IFREMER with Caraïbes software (developed by IFREMER). Sound speed of $1600 \mathrm{~m} / \mathrm{s}$ has been applied for the time to depth conversion.

The submarine surface of Cilaos fan was characterized on the backscatter imagery by acoustic facies ranging from dark (high reflectivity) to light grey (low reflectivity). Five main types of sediment acoustic facies were identified on the echosounder profiles: (1) a hyperbolic unit with irregular hyperboles; (2) a continuous stratified unit characterized by parallel and continuous reflectors; (3) a semi-transparent unit corresponding to a thin surface echo without internal reflectors; (4) a discontinuous stratified unit characterized by stratified echofacies with discontinuous reflectors; and (5) a non-penetrative unit corresponding to a strong and prolonged surface echo. 
A total of thirteen cores were collected and analyzed on the Cilaos turbidite system (Table 1 and Fig. 2A): one was collected in the canyon area (KERO-18); three cores were located in the upper part of the fan (KERO-01, KERO-02 and KERO-11); six cores were collected from the western part of the fan (FOR-C2, KERO-09, KERO-12, KERO-13, KERO-14 and KERO15); and three cores were retrieved in the central part of the fan (FOR-C1, KERO-16, and KERO-17). Sedimentary descriptions were done for all the cores, with a particular emphasis on sediment color, visual grain size and turbidite/hemipelagite/pelagite differentiation. A series of 1-cm-thick sediment slabs were collected for each split core section for Xradiography using a digital X-ray imaging system SCOPIX (Migeon et al., 1999). Digital images were acquired to provide a precise identification of the sedimentary structures. Sediment cores were sampled for grain-size analyses using a Coulter laser microgranulometer (LS130).

In this paper, we used eight cores showing the most representative sedimentary facies of the thirteen cores (Table 1, names in bold and Fig. 3). One core is located in the canyon area (KERO-18), two cores are located in the upper part of the fan (KERO-01 and KERO-11), two cores are in the central part (KERO-16 and KERO-17) and three in the western part (KERO09, KERO-13 and KERO-15). These cores are located on and correlated with the echosounder profiles.

214 Four AMS dates were also obtained, two on core KERO-09 and two on core KERO-16. For each measurement, about 500 specimens of Glogigenrinoides ruber and Glogigerinoides sacculifer were picked from the $>150 \mathrm{~mm}$ fraction. These aliquots were analyzed at the Poznan Radiocarbon Lab., Poland, and at the "Laboratoire de Mesure du Carbone 14" at Sarclay. Reported radiocarbon ages have been corrected for a marine reservoir effect of 400 years and converted to calendar years using CALIB Rev 6.0 (Reimer and Reimer, 2001). Calibrated kilo years before present will be referred as ka.

\section{4. Results}

\subsection{Five volcaniclastic deep-sea fans off La Réunion Island}

The new dataset led to the discovery of five volcaniclastic deep-sea fans showing morphological structures typical of a turbidite system like, canyon, channel and sediment waves (Fig. 2B). They show low reflectivity and display complex geometries, directly constrained by the seafloor morphology. On land, they are related to major erosional features, which constitute the main drainage area of the island. In each case, submarine canyons are directly connected to the main river mouths (Figs. 1 and 2B). 
The Mafate fan (Fig. 2B, 1) is connected to the Cirque of Mafate and coalesces with the Saint-Denis fan (Fig. 2B, 2), which is continuous with the Rivière Saint-Denis. The Salazie fan (Fig. 2B, 3) derives from multiple sources and is connected to the Cirque of Salazie. The Saint-Joseph fan (Fig. 2B, 4) is the only system connected to the Piton de la Fournaise volcano, and considered to be a fan in an embryonic stage. We focus in this paper on the Cilaos fan (Fig. 2B) which is a wide fan connected to the Cirque of Cilaos through the Rivière Saint-Etienne.

The relationship between the activity of these turbidite systems and the largest hurricanes is not completely established but observations of flood impact on land (erosion and transport volume) suggest a direct sediment transfer toward the canyon head during extreme floods.

Volcanic and sedimentary features mainly shape the ocean floor on the abyssal plain (Deplus et al., 2007; Deplus et al., 2009). Volcanic features consist of a series of elongated ridges (named R1 to R4 on Fig. 3B) which display high reflectivity, and include several elongated volcanic structures and isolated seamounts. In the southwestern part of the fan, linear features with high reflectivity are parallel to the Mahanoro fracture zone (Fig. 3). They probably correspond to small fracture zones associated with the offset of the fossil axis to the south. Other topographic highs are visible in the bathymetry and have a low reflectivity contrast (brown areas in Fig. 3B). They correspond to sedimentary accumulations on volcanic highs, like the large ridge named SR at the south of La Réunion (Deplus et al., 2007; Deplus et al., 2009).

\subsection{Morphology and superficial structure of the Cilaos deep-sea fan}

The Cilaos deep-sea fan is the largest volcaniclastic turbidite system off La Réunion Island. On the backscatter image, the Cilaos fan corresponds to a wide area with low reflectivity (Fig. 3A). The whole turbidite system is more than $300 \mathrm{~km}$ long and covers an area of about 15,000 $\mathrm{km}^{2}$. Located southwest of the island, this sedimentary system consists of two main parts: a canyon area (Fig. 3B, in blue) starting at the coast, directly fed by the recurrent flash floods of the Rivière Saint-Etienne; and a deep-sea fan that develops at about $4500 \mathrm{~m}$ of water depth on the abyssal plain (Saint-Ange, 2009; Saint-Ange et al., 2011). The deep-sea fan was initially laterally divided into three main areas: the western, the central, and the eastern parts separated by two NE-SW sub-parallel volcanic ridges called R1 and R2 (Fig. 3) (Saint-Ange, 2009). Advancements in understanding due to new data presented in this paper enable further subdivision of the system into: (1) The proximal fan (Fig. 3B, in red) corresponding to a wide 
area with a low reflectivity; and (2) the distal fan (Fig. 3B, in yellow) which is characterized

262 by elongated structures that are developed between volcanic ridges.

263

264

265

266

267

268

269

270

271

272

273

274

275

276

277

278

279

280

281

282

283

284

285

286

287

288

289

290

291

292

\subsubsection{The Cilaos canyons}

Canyons directly incise the chaotic deposits that form the submarine flanks of the volcanic edifice (Fig. 4) (Lenat and Labazuy, 1990; Oehler et al., 2008). They are $70 \mathrm{~km}$ long and their slopes decrease from $8^{\circ}$ at shallow depth to less than $1^{\circ}$ dip near the base of the volcanic edifice (Fig. 5).

Two wide rectilinear canyons make up the valley area: the Saint-Etienne and the Pierrefonds canyons (Fig. 4B). For each of them, the incision is about $100 \mathrm{~m}$ deep. The Pierrefonds canyon is located in front of the paleo-river outlet of the Rivière Saint-Etienne and is connected to the shelf by many tributaries (Fig. 4C). This canyon is well developed and characterized by high reflectivity on the backscatter image and by a smooth surface on the bathymetric map. It is a flat-bottomed canyon $3 \mathrm{~km}$ wide and $30 \mathrm{~km} \mathrm{long.} \mathrm{Some}$ morphological highs (possible relicts of the chaotic deposits) are visible in the canyon path, inducing local divergences and forming a braided system (Fig. 4A).

The Saint-Etienne canyon is $4 \mathrm{~km}$ wide and seems to be directly connected with the Rivière Saint-Etienne (Fig. 4B). On its western side, limited by the "Etang-Salé" volcanic ridge, it also receives several tributary canyons from a shelf-upper slope sector (Fig. 4). The canyon is partitioned in two distinct areas, the upper and the lower canyon. The upper Saint-Etienne canyon begins at $300 \mathrm{~m}$ water depth and extends to the southern extremity of the "EtangSalé” volcanic ridge at depth of $2200 \mathrm{~m}$ (Fig. 4A). It has a smooth morphology and is characterized by high reflectivity on the backscatter image.

The lower canyon has a rougher morphology on the bathymetry and a mottled appearance on the backscatter image (Figs. 4A and 4B). The chaotic floor of the lower canyon is cut by a narrow incision located in the prolongation of the upper Saint-Etienne canyon (Fig. 4). This incision is $20 \mathrm{~m}$ deep and $13 \mathrm{~km}$ long.

North of the Saint-Etienne and Pierrefonds canyons and north of the "Etang-Salé" ridge, a wide valley is visible. It is a wide trough (about $10 \mathrm{~km}$ wide) with a rough floor and a low reflectivity on the backscatter image named the North Valley (Fig. 4A). A set of gullies (Fig. 4C, yellow dash line) named the North Gullies, cut this valley and join the incision of the lower Saint-Etienne canyon. The North Gullies were connected to the hydrographic network onland (Fig. 4C). These gullies present a rough floor characterized by a mottled facies on the 
backscatter image (Fig. 4B). Local undulations are visible on their western side on the shaded relief map (Fig. 4C and Fig. 6). These undulations are developed in a water depth of about $2000 \mathrm{~m}$. Their geometry varies from symmetrical with a crest in the midslope to asymmetrical at the upslope. Their amplitude ranges from 5 to $30 \mathrm{~m}$ and their wavelength varies from 500 to $700 \mathrm{~m}$ (Fig. 6). The slope gradient is $2.5^{\circ}$. They display similar characteristics to the coarse-grained sediment waves observed on the submarine slopes of the western Canary Islands (Wynn et al., 2000), except for height, which is much greater at La Réunion. Downslope, the North Valley and the two main canyons merge into a single canyon, the Cilaos canyon (Fig. 4) (Saint-Ange, 2009). At the base of slope, the Cilaos canyon (10 km wide) divides into many narrow channels that feed the Cilaos deep-sea fan (Fig. 7).

\subsubsection{The Proximal Fan}

The proximal fan is characterized by a low reflectivity and a wide extent with a maximum width of $120 \mathrm{~km}$ (Figs. 3 and 7). It extends from a depth of 3800 to $4300 \mathrm{mbsl}$, with gradients ranging from $1.5^{\circ}$ to $0.1^{\circ}$ (Fig. 5). Only few sedimentary structures (channels, lobate structures, sediment waves), mainly located on the western side of the turbidite system, are visible at the surface of the proximal fan (Fig. 7).

A main field of sediment waves (Figs. 6 and 7) is located in the channel, at the slope break close to the transition between the canyon and the fan (Fig. 5) at a water depth of 3500-4000 m. These features are particularly highlighted by a contrast in backscatter (Figs. 6 and 7). The crest orientation of the sediment waves is perpendicular to the Cilaos valley axis. Their amplitude is more than $10 \mathrm{~m}$ and their wavelength increases downslope from $1 \mathrm{~km}$ to $3 \mathrm{~km}$ (Fig. 6).

At the base of slope, the proximal fan spreads over the abyssal plain. Its morphology is controlled by the presence of bathymetric highs (often with high reflectivity), which correspond to relief caused by volcanic and sedimentary structures (Fig. 7).

Narrow channels coming from the canyon area mainly develop in the western part of the proximal fan. They form a braided system composed of elongated bodies. This system is bordered by a small field of sediment wave that show the same characteristics as the main sediment waves field (Fig. 7). These bodies are probably small lobes with discontinuous contours. Some narrow channels of the canyon area also extend in the eastern part of the proximal fan but they quickly disappear. They open onto the abyssal plain forming elongated 
324 bodies with low backscatter reflectivity, comparable to those observed in the western part 325 (Fig. 7).

326 On echosounder profiles, chaotic deposits are characterized by an irregular hyperbolic facies 327 (Fig. 8, profile FOR-18). They are slightly incised by small channels in the upper part. Further 328 downslope (Fig. 8, profile FOR-9) the irregular hyperbolic facies changes into a continuously 329 stratified unit, more visible on the western side. On figure 9, the detailed interpretation of 3.5 $330 \mathrm{kHz}$ echosounder profiles shows a vertical succession of three units: U1, U2, and U3. Unit U1

331 (Fig. 9) corresponds to the lowest imaged unit. Stronger reflectors, indicating a high impedance contrast, mark its upper limit. Reflectors are continuous and moderate to high amplitude. Unit U2 (Fig. 9) overlies unit U1 and is semi-transparent (low amplitude). It is thinner than $6 \mathrm{~m}$ and covers the whole distal fan. This transparent unit U2 is mostly covered locally by another stratified unit U3 (Fig. 9). This youngest stratified unit U3 overlies the whole proximal fan. Its thickness decreases distally from the base of slope.

\subsubsection{The Distal Fan}

338 The distal turbidite system comprises western and central parts of the Cilaos fan. It is characterized by elongated structures with low reflectivity, corresponding to narrow channels continuing from the proximal fan (Fig. 10). The reflectivity is low in the channel floors (Fig. 10). It extends from a depth of 4300 to 4500 mbsl, with gradients less than $0.1^{\circ}$ (Fig. 5).

A deeply incised and rectilinear channel characterizes the western part of the distal fan. In the upper part, the incision is lower than $10 \mathrm{~m}$ deep and about $1.5 \mathrm{~km}$ wide. Area of higher relief covered by sediment accumulations divide this main channel into three minor channels (incisions about $10 \mathrm{~m}$ deep) converging westward into a unique, WNW-ESE oriented channel

346 (Fig. 10). This is a highly incised (30 m deep) and long channel (75 km). Its western edge is halted by volcanic highs and it abruptly turns to the southwest (Fig. 10).

348 The central part of the distal fan is composed of a rectilinear channel showing a NE-SW orientation with an incision depth of about $15 \mathrm{~m}$ that increases downslope (Fig. 10). The volcanic ridges seem to directly control the channel direction. To the south, the channel in the central part of the distal fan joins the same WNW-ESE oriented channel from the western part of the fan (Fig. 10). This WNW-ESE oriented channel starts somewhere upstream of these confluences, but it disappears in the eastern part. No structures are visible on the bathymetry and the backscatter image (Fig. 10). 
The Cilaos turbidite system ends in a small fracture zone associated to the offset of the Mahanoro fracture zone, where no depositional structures of the distal fan are visible (Fig. 10).

On echosounder profiles, the distal fan is characterized by the presence of units U1 and U2 over the whole area (Figs. 8 and 9). Unit U3 covers most of the eastern and central parts of the distal fan. In the western distal part, channels are observed. While moving away from the island the U-shaped valley, visible on profile FOR-13 (Fig. 8), has evolved into narrow Vshaped valleys with non-penetrative echofacies in the channel floors as visible on profiles FOR-45 and ERO2-07 (Fig. 8). In the central part, a wide shallow U-shaped valley has developed. The width of this channel decreases from 4 km on profiles FOR-11 and FOR-13 (Fig. 8) to $1 \mathrm{~km}$ on profile ERO2-07 (Fig. 8). The channel floor passes from continuous (profile FOR-13, Figs. 6 and 8B) to discontinuous (profile FOR-45, Figs. 8 and 9) stratified units with superficial high-amplitude reflectors. The eastern part is characterized by continuous bedded facies with few channelized structures that are only visible on profiles FOR-45 and ERO2-07 (Fig. 8). A small field of sediment waves is visible on profile FOR-13 (Figs. 6 and 8) located on an overbank. Their geometry is asymmetrical. They have an amplitude of 4 to $6 \mathrm{~m}$, a wavelength of about 700 to $850 \mathrm{~m}$ (Fig. 6) and their slope gradient is $0.2^{\circ}$. They display similar characteristics to the coarse-grained sediment waves observed on the submarine slopes of the western Canary Islands (Wynn et al., 2000).

No typical turbidite levee structure can be identified in the distal fan on the channel sides in the $3.5 \mathrm{kHz}$ profiles. Only a few features suggest levee structures in the distal part of the fan which are visible on profiles FOR-45, ERO2-07, FOR-4a, and FOR-4b (Fig. 8).

\subsection{Sedimentary Facies}

Cores retrieved in the Cilaos fan are mainly composed of brown clay, silt and sand. The silty and sandy layers are characterized by a dark color due to the dominance of volcaniclastic elements (Fig. 11). Glass shards, angular olivine, pyroxene, oxides and feldspar crystals, bioclasts and rock fragments are the main petrographic components of these sands.

\subsubsection{Sedimentary facies in the canyon area and the proximal fan}

The three cores KERO-18, collected in the canyon area, and KERO-01 and KERO-11 collected on the proximal fan, best illustrate the sedimentation in the canyon area and the proximal fan. Core KERO-18 is located in the Saint-Etienne canyon about $15 \mathrm{~km}$ from the 
shoreline at $2056 \mathrm{~m}$ water depth. It recovered the only samples (about $30 \mathrm{~cm}$ ) of coarsegrained sand and gravel (Fig. 5) suggesting the passing of high-density turbidity currents.

Cores KERO-01 and KERO-11 are within the sediment wave field on the northwest side of the main channel (Figs. 5 and 7). Thin sand layers $(1-5 \mathrm{~cm})$, with maximum grain size ranging from 100 to $350 \mu \mathrm{m}$, interbedded with clay comprise the first meter of KERO-01 (Fig. 5). This succession overlies two meters of bioturbated clay (alternation of light and dark brown clay layers) interstratified with sandy layers (1 or $2 \mathrm{~cm}$ thick) and silty laminae. The light brown clay is dominated by calcareous sediment (nannoplankton and foraminifera), while the dark brown clay mainly contains siliceous organisms (radiolarians and diatoms). Between 3.06 meters below seafloor (mbsf) and 3.17 mbsf, the core shows a normally graded sandy interval with no visible structure, ranging from silty clay to coarse sand. The deepest part of the core is composed of $73 \mathrm{~cm}$ of brown clay. In this core, thin fine sand layers are interpreted as fine-grained turbidite deposits. The thickest sandy layer (11 $\mathrm{cm}$ thick) is interpreted as a coarse turbidite deposit. The location of the core in the sediment wave field and the types of deposits (thin sandy layers) suggest that these deposits were emplaced by overflow of a high density turbidity currents

KERO-11 is mostly composed of sand (Figs. 5 and 11). The top of the core shows a $1 \mathrm{~m}$ thick sandy layer (grain size between 150 and $200 \mu \mathrm{m}$ ) that is normally graded (Fig. 11). The base of the layer is structureless and is overlain by an interval with horizontal laminations (foraminifera-rich laminae including bathyal foraminifers) (Fig. 11). A second $30 \mathrm{~cm}$ thick normally graded sandy layer (grain size between 100 and $200 \mu \mathrm{m}$ ) is present in the lower part of the core at about 1.75 mbsf. These two layer are composed of the Ta and Tb division of the Bouma sequence (Bouma, 1962). These sandy layers are interpreted as high-density turbidite deposits. Based on grain size, we have calculated a sand/mud ratio of about 95:5.

In this upper part of the Cilaos turbidite system, the Kullenberg corer failed to recover in three locations, one in the canyon area and two in the proximal fan, suggesting clean sand layer (Fig. 2).

\subsubsection{Sedimentary facies in the distal fan}

In the distal fan, sediments are finer than in the proximal fan except for core KERO-13 (Fig. 5). A change in sedimentary facies and successions is observed between the western part and the central part. 
418 KERO-16 (4.95 m long) and KERO-17 (5.34 m long) are located in the central part of the 419 Cilaos turbidite system (Fig. 10). KERO-16 is located on the northwest side of the channel and KERO-17 is from the channel floor (Figs. 10 and 9).

421 The first 1.4 meters of KERO-16 are characterized by silty layers (grain size between 50 and $100 \mu \mathrm{m}$ ) thinner than $1 \mathrm{~cm}$ interbedded with muddy hemipelagic intervals. The base of silty layers is composed of laminated intervals. Muddy intervals are bioturbated and contain foraminifera. Two AMS date were obtained in these muddy intervals at $0.6 \mathrm{~m}$ and $1.22 \mathrm{~m}$ below sea floor (Table 2). They are dated respectively at $13.12 \mathrm{ka}$ and $34.42 \mathrm{ka}$. These silty deposits correspond to fine-grained turbidites with a sand/mud ratio of 20:80. The location of the core on the channel edge and the succession of thin silty layers suggest that these deposits are overflow deposits corresponding to unit U3, which is particularly thin on the channel side (Fig. 9). Between $1.4 \mathrm{mbsf}$ and $4.95 \mathrm{mbsf}$, the core is composed of clay layers (alternation of light brown clay and darker brown clay) with bioturbation. This sedimentary facies correlates with the semi-transparent unit U2 observed in the echosounder profiles (Fig. 9)

432 KERO-17 shows a succession of eight sandy and silty layers, interbedded with muddy 433 deposits. The thickness of silty and sandy layers varies from $1 \mathrm{~cm}$ in the lower part of the core to $50 \mathrm{~cm}$ in the upper part and the grain size ranges from 50 to $150 \mu \mathrm{m}$ (Figs. 5 and 9). The upper first $75 \mathrm{~cm}$ of the core are composed of a thick normally graded sandy layer. The base of the layer is structureless (Ta division of the Bouma sequence) and is overlain by an interval with planar and cross laminations ( $\mathrm{Tb}$ and Tc division of the Bouma sequence). Two other sandy layers are visible over this thick unit at 0.8 and 1.15 mbsf (Fig. 11). Their thicknesses are 8 and $15 \mathrm{~cm}$ respectively and they are characterized by planar and cross laminations (Fig. 11). These three units were interpreted as coarse-grained turbidite with a sand/mud ratio of 70:30. Between 1.30 and 5 mbsf four sandy units are interbedded with muddy deposits that contained well preserved bathyal foraminifera. They are characterized by a thickness of about $5 \mathrm{~cm}$ and normally graded fine sand with cross laminations (Tc division of the Bouma sequence). The clay layers are highly bioturbated with low foraminifera content. These deposits correspond to fine grained turbidite deposits. The last sandy layer, at $5.05 \mathrm{~m}$ bsf, is $15 \mathrm{~cm}$ thick and composed of a basal structurless layer (Ta division of the Bouma sequence) and is overlain by an interval with planar and cross laminations (Tb and Tc division of the Bouma sequence). In the echosounder profiles, KERO-17 correlates with high-amplitude reflectors (Fig. 9) typical of unit U3. 
The two cores KERO-09 and KERO-15 are located on the northwest side of the main channel of the western part of the study area, at about $215 \mathrm{~km}$ from the coast of the island for KERO09 and $280 \mathrm{~km}$ for KERO-15 (Fig. 10). They recovered to $6.27 \mathrm{~m}$ and $6.68 \mathrm{~m}$ of sediment (Table 1) and show similar sedimentary successions to one another (Figs. 5 and 9). This succession is characterized by a thick layer of clay in the top of cores (respectively 2 and $3 \mathrm{~m}$ thick for KERO-09 and KERO-15) showing alternation between light brown clay and highly biorturbated darker brown clay. Two AMS date were obtained in the light brown clay (dominated by calcareous sediments) for core KERO-09 at $0.03 \mathrm{~m}$ and $0.69 \mathrm{mbsf}$ (Table 2). They are dated at $13.30 \mathrm{ka}$ and $42.6 \mathrm{ka}$ respectively (Table 2). This clay unit overlays a succession of four sandy layers for KERO-09 and seven sandy layers for KERO-15 (grain size between 50 and $150 \mu \mathrm{m}$ ). These sandy layers (about one sequence per meter) are 15-20 cm thick and up to $35 \mathrm{~cm}$ in KERO-15. They are composed of well-sorted fine sand with both planar and cross laminations overlain by silty laminations and clay (Fig. 11). This succession corresponded to Tb, Tc, Td and Te Bouma intervals (Bouma, 1962). In the dark sandy layers, laminations are underlain by white laminae with a high content of foraminifera (Fig. 11). These deposits are typical of low-density turbidites with a sand/mud ratio of 40:60 for core KERO-09 and of 30:70 for KERO-15.The clay-rich interval correlates with the semitransparent unit U2 observed on echosounder profiles (Fig. 9) and the turbidite succession corresponds to the stratified unit U1.

KERO-13 is located near core KERO-09, in the channel floor of the western part of the Cilaos Fan (Fig. 10). It is composed of two units of massive sand, fine-grained sand in the upper part and medium to coarse sand in the lower part of the section (small pebbles and high preserved bathyal foraminifera) (Fig. 5). It is highly deformed by the coring process (Piston effect). These deposits are interpreted as high density turbidity currents with a sand mud ratio of 95:5.

\section{Discussion}

\subsection{Sedimentary architecture of the Cilaos deep-sea fan}

The geographic partitioning of sediment accumulation allows the definition of two areas of sedimentation.

- 1) The proximal fan, which corresponds to a wide area mainly composed of a few shallow channels (Figs. 3 and 7) and characterized by relatively coarse-grained turbidites in the upper depositional units of sediment core samples (Figs. 5 and 11). 
- 2) The distal fan, characterized by a system of well-defined channels (Figs. 3 and 10), and by fine-grained turbidites in lower depositional units of sediment core samples (Figs. 5 and 11).

The Cilaos turbidite system is classified as a sand rich system (Saint-Ange et al., 2011). According to the model of sand-rich and point-source deep-sea fans established by Reading and Richards (1994), a sand-rich submarine fan is moderate in size, tends to have a radial shape, and is characterized by channelized lobes and unconfined channels without welldeveloped levees. This setting is partly comparable with the proximal part of the Cilaos fan, where an unconfined channel system with lobate structures is observed, while downslope it evolves into a confined system with well incised channels as observed in the western and central distal fan. Here, we suggest that the preexisting seafloor topography highly influenced the morphology of the fan with the flow being confined among volcanic ridges. This favored the development of small and well-incised channels, whose pattern was controlled by the abyssal plain morphology in most part of the distal fan.

In the proximal fan, the turbidity currents moved on relatively steep slope and have deposited a high content of coarse-grained sediment, as observed on core KERO-11 and KERO-17. Normark and Piper (2001) suggest that coarse-grained turbidity currents tend to be faster and more erosive than fine-grained turbidity currents, especially if they are moving on relatively steep slopes. The lack of levee in the proximal Cilaos fan can be explained by a strongly erosive turbidity current enriched in coarse-grained sediment as observed in the Lagoa Parda oil field, where most of the deep channels filled with coarse sediment do not have associated levees (Bruhn and Walker, 1997). In the distal Cilaos fan, the percentage of sand decreases but remains significantly high (about 40\%), which explain the low development of the levees observed on echosounder profiles FOR-45, Ero2-07, FOR-4a and FOR-4b (Fig. 8).

The complex geometry of the Cilaos fan is controlled by the steep submarine slopes of La Réunion, the morphology of the basin, and by abundance of sediment supply (Saint-Ange et al., 2011).

\subsection{Sediment source of turbidity currents}

Studies on the morphology of La Gomera Island or Tenerife Island, with a similar volcanic context and drainage pattern, show that submarine canyons are often found off major river mouths and are incised by turbidity currents (Krastel et al., 2001; Llanes et al., 2009; Mitchell et al., 2003). Some turbidites reveal a high component of upper bathyal foraminifers 
513 (Schneider et al., 1998) suggesting that clastic material was stored on the upper slope before it 514 was removed by turbidity current or was delivery directly from the subaerial fluvial system. 515 The high preservation of bathyal formainifers and the location of canyons offshore major 516 river mouths suggest a hyperpycnal activity before the development of insular shelves that led 517 to the disconnection of the canyons from their fluvial sources (Mitchell et al., 2003). At La 518 Réunion, the large newly discovered turbidite systems are directly linked to the hydrographic 519 network and high preserved bathyal foraminifera are observed in the distal cores, suggesting a 520 climatic influence and the role of hyperpycnal processes in the generation of turbidity 521 currents. As proposed by Saint-Ange et al. (2011), the main source of sediment on the Cilaos fan is the Rivière Saint-Etienne that feeds the system by hyperpycnal flows, but this detailed study suggests that other processes can also occur.

The well-developed Pierrefonds canyon and the upper part of the Saint-Etienne canyon, that show high reflectivity and smooth floor (Fig. 4), are connected to the coast by narrow tributary canyons (Fig. 4) and not directly to the present river mouth as for the main SaintEtienne canyon head. This configuration suggests a contribution of sediment supply from coastal processes to the canyon. The limited size and incision of gullies feeding the SaintEtienne canyon at the East of the "Etang-Salé” ridge ("Etang-Salé” beach) and the larger extension of the insular shelf in this coastal sector are in good agreement with the existence of coastal processes. Local slope instabilities triggered by waves can be invoked.

The high reflectivity visible in the Pierrefonds canyon and the Upper part of the Saint-Etienne canyon and the coarse-grained deposits of core KERO-18 suggest the occurrence of coarsegrained and high energy sediment flows. The large size and the mature morphology of the Pierrefonds canyon can be explained by its location in front of the paleo-river outlet, which supplied a large volume of sediment when the main river mouth was located in Pierrefonds. The North Valley and the lower part of the Saint-Etienne canyon are different, with a rough floor corresponding to a mottled appearance on the backscatter image. The rough seafloor can be related to local instabilities (Le Friant et al., 2011; Oehler et al., 2008). This instability seems younger than the Saint-Etienne canyon because the chaotic deposits fill the lower Saint-Etienne canyon (Fig. 4). The North Gullies and the narrow incision in the lower Saint-

542 Etienne canyon cut the chaotic deposits, indicating a recent feeding of the system by recurrent 543 flow processes generated from the hydrographic network.

544 In summary, the Cilaos turbidite system is fed by several types of sources: direct feeding by the present river supply, local slope instabilities in the coastal area triggered by waves, and 
546 local submarine events as demonstrated by chaotic deposits in the North Valley and in the 547 lower Saint-Etienne canyon.

\section{5.3. Model of Cilaos turbidite system growth}

549 Three depositional units are mapped in the Cilaos fan, based on the correlation between 550 echosounder profiles and cores. In the distal part, fine-grained turbidites showing cross551 bedded structures, visible on core KERO-15 and KERO-09, are linked to the stratified unit 552 U1 (Fig. 9). The thick clay layer, which covers these turbidites, is strongly correlated to the 553 transparent unit U2 (Fig. 9). The sandy turbidites, located in the upper part of core KERO-01, 554 KERO-11, KERO-16 and KERO-17 are linked to the stratified unit U3 (Fig. 9). These three 555 units were recognized over the entire fan using echosounder profiles. Some extract of interpreted profiles across the three parts of the fan are shown in figure 9. Based on this interpretation, three synthetic longitudinal sections showing the distribution of the three units across the fan were developed (Fig. 9). This shows three stages in the construction of the Cilaos fan.

The first stage (T1) (Fig. 12), corresponding to the unit U1, is characterized by long run out turbidity currents that spread over the entire fan and which deposited sands that were 10-30 cm thick. These deposits are overlain by 2-3 m of hemipelagic mud. Using the AMS dates we calculated a sedimentation rate for the two cores KERO-09 and KERO16 to estimate the age of the top of unit U1. We obtained a sedimentation rate of 2.25 (KERO-09) and $2.9 \mathrm{~cm} / \mathrm{ka}$ (KERO-16) for the upper Pleistocene and the Holocene. These results are comparable to the minimum sedimentation rate of $1.9 \mathrm{~cm} / \mathrm{ka}$ proposed by Ollier et al. (1998) in this area during the same period. Their results are based on micropaleontological analyses. Using a mean rate of $2.5 \mathrm{~cm} / \mathrm{ka}$, we obtain an age of about $120 \mathrm{ka}$ for the last turbidite observed on core KERO09 and an age of about $80 \mathrm{ka}$ for the last turbidite observed on core KERO-15. The oldest stage (U1) is characterized by intense turbidity current activity as demonstrated by the succession of thick sandy turbidite in cores from distal location (more than $250 \mathrm{~km}$ from the coast).

The second stage (T2) (Fig. 12) in the construction of the Cilaos fan corresponds to unit U2. This layer is visible over the entire fan (Fig. 9), except for the more proximal parts. It is characterized by a thick layer of hemipelagic mud, which we interpret as marking an interruption of turbidity current activity. The upper limit of unit U2, visible in core KERO-16, is characterized by a sandy layer deposited at $1.45 \mathrm{~m}$ from the top of core, corresponding at 
the first turbidite of unit U3. Based on the AMS date of KERO-16, the age of limit U2/U3 is estimated about $42 \mathrm{ka}$.

The third stage (T3) (Fig. 12), corresponding to the unit U3, represents the most recent activity of the Cilaos fan. This unit is limited to the proximal fan and to a recent infilling of the channels of the distal part, and corresponds to coarse-grained turbidites. On echosounder profiles, most of the channels of the distal area are capped by the transparent unit U2 (Fig. 8, profiles FOR-13 to FOR-4a), indicating that the channels are older than the recent turbidite deposits belonging to unit U3. The recent turbidity current activity induced local reactivation of channels with erosion of the hemipelagic drape (unit U2) and resulted in deposition of turbidites.

The limit between units U3 and U2 can be correlated to the end of effusive activity of the Piton des Neiges at about 30 ka (Gillot and Nativel, 1982), while the limit between unit U2 and $\mathrm{U} 1$, between 80 and $120 \mathrm{ka}$, can be correlated to highstand sea levels of the last interglacial. At present, it remains difficult to establish whether the different stages in the construction of the Cilaos fan are associated with the volcanic activity of La Reunion Island, the cirques formation, or if they result from global climatic change of the late Quaternary as suggested by Quidelleur et al. (2008).

\subsection{Flow type and dynamics}

As demonstrated, the recent activity of the Cilaos turbidite system occurs in canyons, in the proximal fan and in some of the channels of the distal fan. Sandy layers dominate the sedimentary facies. The proximal fan is a radial-shaped fan with a diameter of 100 to $150 \mathrm{~km}$. Only few structures are observed in this part of the fan; mainly a braided system of unconfined channels in the western part and lobe complexes. These characteristics suggest that density currents are sand-rich with high energy during their flow into the canyon where the slope angles range from $8^{\circ}$ on the upper slope to $1^{\circ}$ at $4000 \mathrm{~m}$ water depth (Fig. 5). They probably reach the base of the slope with a relative high velocity and have the ability to flow and transport coarse sediment (sand) over more than $100 \mathrm{~km}$. The available cores for the proximal fan are not located in the main flow axis and provide an approximation of the grainsize distribution there, likely relatively coarse sand.

The field of sediment-waves observed in the upper part of the proximal fan is explained by a change in flow dynamic of the density currents, probably due to the occurrence of a slope break (corresponding to the base of the volcanic edifice) (Fig. 5). Upslope migration, different 
asymmetrical shapes and lack of cross-bedding (Figs. 5 and 11) suggest that this field of

611 sediment-waves was cyclic steps (Cartigny et al., 2011). The change in dynamics could correspond to a hydraulic jump implying the expansion of the flow volume, the increase of flow turbulence and the rapid decrease of the flow velocity (Garcia and Parker, 1989; Garcia, 1993; Piper and Normark, 2001). This change could induce the deposition of extended lobes without the incision of a deep channel and the development of sandy sediment waves at the “channel-lobe” transition as described in other turbidite systems (Morris et al., 1998; Wynn et al., 2002; Wynn and Stow, 2002).

618 Analyses of the Cilaos deep-sea fan shows that the distal fan is marked by older turbidity current activity characterized by extensive turbidite deposits (Unit U1) and possible synchronous incision of channels over $300 \mathrm{~km}$ from the island. The turbidity currents producing these sedimentary bodies probably had characteristics quite different from the recent turbidity flows. Unlike the proximal fan, the old turbidite activity of the distal fan shows fine grained deposits composed of very fine sands and silts (U1 in the core KERO-09 and KERO-15). These deposits are quite different from the coarse-grained turbidites of core KERO-13, corresponding to the recent activity of the distal fan. The presence of structures suggesting levee deposits on the channel sides (as shown on echosounder profiles) combined with the extensive channel system is in good agreement with a lower density and a higher mud content of the flow compared to the most recent turbidites (Unit U3). All these characteristics suggest a system with a more efficient sediment transport, probably more comparable to a mixed system (mud/sand). Throughout the past activity of the Cilaos turbidite fan, we suggest that the sediment source could have been quite different than the present sediment source, either with a higher contribution of hemipelagic sediment (reworking of the submarine slope) or higher mud content in the island erosion products (in relation with different chemical weathering and possible climate variation).

\section{Conclusions}

636 Five volcaniclastic turbidite systems were identified off La Réunion Island. The Cilaos deepsea fan constitutes a complex turbidite system, over $250 \mathrm{~km}$ long, that involves large amount of sediment. New high-resolution multibeam and subbottom data and piston cores allow the first accurate sedimentary characterization of this volcaniclastic system. The Cilaos deep-sea

640 fan is connected to the coast through two major canyons linked to the Rivière Saint-Etienne, which supplies sand derived from the Piton des Neiges volcano. These canyons fed a fan 
643

644

645

646

647

648

649

650

651

652

653

654

655

656

657

658

659

660

661

662

663

664

665

666

667

668

669

670

671

672

673

674

appears atypical because of a preexisting seafloor topography that has clearly influenced depositional processes during the edification of the deep-sea volcaniclastic fan.

A detailed study of the canyons allows the identification of several processes feeding turbidity currents. In addition to a direct feeding by the river with the generation of hyperpycnal flows as observed in other works, a feeding by local instabilities is also observed. Slope instabilities are occurring along the coast and the slope of the volcano, which are able to bring significant sediment volumes in an oceanic basin adjacent to a volcano.

The recent Cilaos fan was constructed in three stages. A first stage, older than $80 \mathrm{ka}$, a second step between 42 and $80 \mathrm{ka}$, characterized by an interruption of the turbidite activity and a third stage, younger than $42 \mathrm{ka}$, corresponding to the recent turbidite activity mainly in the proximal fan.

The Cilaos fan can be defined as a unique sand-rich turbidite system showing an atypical large extent. The study of such a turbidite system illustrates the importance of the marine volcaniclastic sedimentation, too often underestimated in the studies of volcanic island evolution.

\section{Acknowledgments}

This paper is dedicated to Bruno Savoye (1961-2009), geologist and geophysicist at IFREMER, who had initiated this research project offshore La Réunion Island. The authors thank the crew and scientific teams for the high-quality data recovery during the 2006 FOREVER cruise aboard the R/V L'Atalante, the 2006 ERODER1 cruise aboard the BHO Beautemps-Beaupré, and the 2008 ERODER 2 cruise aboard the RV Meteor. Financial support was provided by the “Conseil Régional de La Réunion” and by IFREMER. Internal reviews by David Mosher and Robbie Bernnett helped clarify our ideas and writing. The authors thank Dr. Claudia Romagnoli, an anonymous reviewer, and Editor David J.W. Piper whose comments and suggestions contributed to improve the original manuscript.

\section{References}

Acosta, J., Uchupi, E., Munoz, A., Herranz, P., Palomo, C., Ballesteros, M., Grp, Z.E.E.W., 2003. Geologic evolution of the Canarian Islands of Lanzarote, Fuerteventura, Gran Canaria and La Gomera and comparison of landslides at these islands with those at Tenerife, La Palma and El Hierro. Marine Geophysical Researches 24, 1-40 
681

682

683

684

685

686

687

688

689

690

691

692

693

694

695

696

697

698

699

700

701

702

703

704

705

706

707

708

709

710

711

712

713

714

715

716

717

718

719

720

721

722

723

724

Arnaud, N., 2005. Les processus de demantelement des volcans, le cas d'un volcan bouclier en milieu oceanique : le Piton des Neiges (Ile de La Réunion).Université de La Réunion, France, pp. 422

Bachelery, P., Chevallier, L., Gratier, J.P., 1983. Structural characteristics of historical eruptions of the Piton de la Fournaise (Reunion Island). Comptes Rendus De l'Academie Des Sciences Serie II 296, 1345-1350

Barcelo, A., Robert, R., Coudray, J., 1997. A major rainfall event: The 27 February 5 March 1993 rains on the southeastern slope of Piton de la Fournaise massif (Reunion Island, southwest Indian Ocean). Monthly Weather Review 125, 3341-3346

Bonneville, A., Barriot, J.P., Bayer, R., 1988. Evidence from geoid data of a hotspot origin for the southern Mascarene Plateau and Mascarene Islands (Indian Ocean). Journal of Geophysical Research 93, 4199-4212

Bosman, A., Chiocci, F.L., Romagnoli, C., 2009. Morpho-structural setting of Stromboli volcano revealed by high-resolution bathymetry and backscatter data of its submarine portions. Bulletin of Volcanology 71, 1007-1019

Bouma, A.H., 1962. Sedimentology of some flysch deposits: a graphic approach to facies interpretation. Elsevier, Amsterdam 168 pp

Bret, L., Fevre, Y., Join, J.L., Robineau, B., Bachelery, P., 2003. Deposits related to degradation processes on Piton des Neiges volcano (Reunion Island): overview and geological hazard. Journal of Volcanology and Geothermal Research 123, 25-41

Bruhn, C.H.L., Walker, R.G., 1997. Internal architecture and sedimentary evolution of coarsegrained, turbidite channel-levee complexes, Early Eocene Regência Canyon, Esperíto Santo Basin, Brazil. Sedimentology 44, 17-46

Cartigny, M.J.B., Postma, G., van den Berg., J., Mastbergen, D.R., 2011. a comparative study of sediment waves and cyclic steps based on geometries internal structures and numerical modeling. Marine geology 280, 40-56

Casalbore, D., Romagnoli, C., Chiocci, F., Frezza, V., 2010. Morpho-sedimentary characteristics of the volcaniclastic apron around Stromboli volcano (Italy). Marine Geology 269, 132-148

Courtillot, V., Davaille, A., Besse, J., Stock, J., 2003. Three distinct types of hotspots in the Earth's mantle. Earth and Planetary Science Letters 205, 295-308

De Voogd, B., Palome, S.P., Hirn, A., Charvis, P., Gallart, J., Rousset, D., Danobeitia, J., Perroud, H., 1999. Vertical movements and material transport during hotspot activity: Seismic reflection profiling offshore La Reunion. Journal of Geophysical Research-Solid Earth 104, 2855-2874

Deniel, C., Kieffer, G., Lecointre, J., 1992. New Th-230-U-238 and C-14 age determinations from Piton des Neiges volcano, Reunion-A revised chronology for the Differentiated Series Journal of Volcanology and Geothermal Research 51, 253-267

Deplus, C., de Voogd, B., Dyment, J., Bissessur, D., Sisavath, E., Depuiset, F., Mercier, M., 2009. New insights on the oceanic lithosphere at La Reunion hotspot volcano, EGU Geophysical Research Abstracts 11-5728, Vienna.

Deplus, C., de Voogd, B., Dyment, J., Depuiset, F., Sisavath, E., FOREVER scientific party, 2007. Does the Reunion Hotspot Volcano Emplace on a Fossil Ridge or a Fracture Zone?, AGU 2007 Fall Meeting Eos Trans. AGU V31F-05, San Francisco.

Deplus, C., Le Friant, A., Boudon, G., Komorowski, J.-C., Villemant, B., Harford, C., Segoufin, J., Cheminee, J.-L., 2001. Submarine evidence for large-scale debris avalanches in the Lesser Antilles Arc. Earth and Planetary Science Letters 192, 145-157

Duncan, R.A., Backman, J., Peterson, L., 1989. Reunion hotspot activity through tertiary time: initial results from the Ocean Drilling Program, leg 115. Journal of Volcanology and Geothermal Research 4, 193-198 
Fèvre, Y., 2005. Mécanismes et vitesses d'érosion à l'échelle géologique sur une île volcanique jeune à relief élevé - La Réunion (Océan Indien).Université de la Réunion, France, pp. 217

Gailler, L.S., Lenat, J.F., Lambert, M., Levieux, G., Villeneuve, N., Froger, J.L., 2009. Gravity structure of Piton de la Fournaise volcano and inferred mass transfer during the 2007 crisis. Journal of Volcanology and Geothermal Research 184, 31-48

Garcia, M., Parker, G., 1989. Experiments on hydraulic jumps in turbidity currents near a canyon-fan transition. Science 245, 393-396

Garcia, M.H., 1993. Hydraulic Jumps in Sediment-Driven Bottom Currents. Journal of Hydraulic Engineering 119, 1094-1117

Garcia, M.O., Hull, D.M., 1994. Turbidites from giant Hawaiian landslides-results from Ocean Drilling Program site-842. Geology 22, 159-162

Garcin, M., Poisson, B., Pouget, R., 2005. High rates of geomorphological processes in a tropical area: the Remparts River case study (Reunion Island, Indian Ocean). Geomorphology 67, 335-350

Gillot, P.Y., Nativel, P., 1982. K-Ar chronology of the ultimate activity of Piton des Neiges volcano Réunion Island, Indian Ocean. Journal of Volcanology and Geothermal Research 13, 131-146

Gillot, P.Y., Nativel, P., 1989. Eruptive history of the Piton de la Fournaise volcano, Réunion Island, Indian Ocean. Journal of Volcanology and Geothermal Research 36, 53-65

Krastel, S., Schmincke, H.U., Jacobs, C.L., 2001. Formation of submarine canyons on the flanks of the Canary Islands. Geo-Marine Letters 20, 160-167

Le Friant, A., Boudon, G., Arnulf, A., Roberson, R.E.A., 2009. Debris avalanche deposits offshore St. Vincent (west indies): Impact of flank-collapse events on the morphological evolution of the island. Journal of Volcanology and Geothermal Research 179, 1-10

Le Friant, A., Harford, C., Deplus, C., Boudon, G., Sparks, S., Herd, R., Komorowski, J.-C., 2004. Geomorphological evolution of Montserrat (West Indies): importance of flank collapse and erosional processes. Journal of Geological Society London 161, 147-160

Le Friant, A., Lebas, E., Clément, V., Boudon, G., Deplus, C., de Voogd, B., Bachélery, P., 2011. A new model for the evolution of La Réunion volcanic complex from complete marine geophysical surveys. Geophysical Research Letter 38, 10.1029/2011GL047489

Lenat, J.F., Boivin, P., Deniel, C., Gillot, P.Y., Bachelery, P., Fournaise, T., 2009. Age and nature of deposits on the submarine flanks of Piton de la Fournaise (Reunion Island). Journal of Volcanology and Geothermal Research 184, 199-207

Lenat, J.F., Labazuy, P., 1990. Morphologies et structures sous-marines de La Réunion.

Llanes, P., Herrera, R., Gómez, M., Muñoz, A., Acosta, J., Uchupi, E., Smith, D., 2009. Geological evolution of the volcanic island La Gomera, Canary Islands, from analysis of its geomorphology. Marine Geology 264, 123-139

Louvat, P., Allegre, C.J., 1997. Present denudation rates on the island of Reunion determined by river geochemistry: Basalt weathering and mass budget between chemical and mechanical erosions. Geochimica et Cosmochimica Acta 61, 3645-3669

Malengreau, B., Lenat, J.F., Froger, J.L., 1999. Structure of Reunion Island (Indian Ocean) inferred from the interpretation of gravity anomalies. Journal of Volcanology and Geothermal Research 88, 131-146

Masson, D.G., Watts, A.B., Gee, M.J.R., Urgeles, R., Mitchell, N.C., Le Bas, T.P., Canals, M., 2002. Slope failures on the flanks of the western Canary Islands. Earth-Science Reviews 57, 1-35

McDougall, I., 1971. The geochronology and evolution of the young volcanic island of Réunion, Indian Ocean. Geochimica et Cosmochimica Acta 35, 261-288 
801

802

803

804

805

806

807

808

809

810

811

812

813

814

815

816

817

818

819

820

821

822

Michon, L., Saint-Ange, F., 2008. Morphology of Piton de la Fournaise basaltic shield volcano (La Reunion Island): Characterization and implication in the volcano evolution. Journal of Geophysical Research-Solid Earth 113, B03203.10.1029/2005JB004118

Migeon, S., Weber, O., Faugères, J.-C., Saint-Paul, J., 1999. SCOPIX: A new X-ray imaging system for core analysis. Geo-Mar. Lett. 18, 251-255

Mitchell, N.C., Dade, W.B., Masson, D.G., 2003. Erosion of the submarine flanks of the Canary Islands. Journal of Geophysical Research-Earth Surface 108, F16002.10.1029/2002JF000003

Moore, J.G., Clague, D.A., Holcomb, R.T., Lipman, P.W., Normark, W.R., Torresan, M.E., 1989. Prodigious Submarine Landslides on the Hawaiian Ridge. Journal of Geophysical Research 94, 17. 465-484

Morgan, W.J., 1981. Hot spot tracks and the opening of the Atlantic and Indian Oceans, The Sea.

Morris, S.A., Kenyon, N.H., Limonov, A.F., Alexander, J., 1998. Downstream changes of large-scale bedforms in turbidites around th Valencia channel mouth, north-west Mediterranean: implications for paleoflow reconstruction. Sedimentology 45, 365-377

Normark, W.R., Piper, D.J.W., 1991. Initiation processes and flow evolution of turbidity currents: implications for depositional record, in Osborne, R.H. (Ed), From Shoreline to Abyss: Contribution in LMarine Geology in Honor of Francis Parker Shepard. SEPM Special Publication 46, 207-230

Oehler, J.-F., Lénat, J.-F., Labazuy, P., 2008. Growth and collapse of the Reunion Island volcanoes. Bulletin of Volcanology 70, 717-742

Oehler, J.F., de Vries, B.V., Labazuy, P., 2005. Landslides and spreading of oceanic hot-spot and arc shield volcanoes on Low Strength Layers (LSLs): an analogue modeling approach. Journal of Volcanology and Geothermal Research 144, 169-189

Oehler, J.F., Labazuy, P., Lenat, J.F., 2004. Recurrence of major flank landslides during the last 2-Ma-history of Reunion Island. Bulletin of Volcanology 66, 585-598

Ollier, G., Cochonat, P., Lenat, J.F., Labazuy, P., 1998. Deep-sea volcaniclastic sedimentary systems: an example from La Fournaise volcano, Reunion Island, Indian Ocean. Sedimentology 45, 293-330

Peltier, A., Famin, V., Bachelery, P., Cayol, V., Fukushima, Y., Staudacher, T., 2008. Cyclic magma storages and transfers at Piton de La Fournaise volcano (La Reunion hotspot) inferred from deformation and geochimical data. Earth and Planetary Science Letters 270, 180-188

Peltier, A., Staudacher, T., Bachelery, P., Cayol, V., 2009. Formation of the April 2007 caldera collapse at Piton de La Fournaise volcano: Insights from GPS data. Journal of Volcanology and Geothermal Research 184, 152-163

Piper, D.J.W., Normark, W.R., 2001. Sandy Fans - From Amazon to Hueneme and Beyond. AAPG Bulletin 85, 1407-1438

Quidelleur, X., Hildenbrand, A., Samper, A., 2008. Causal link between Quaternary paleoclimatic changes and volcanic islands evolution. Geophysical Research Letters 35, L02303.10.1029/2007GL031849

Quidelleur, X., Holt, J.W., Salvany, T., Bouquerel, H., 2010. New K-Ar ages from La Montagne massif, Reunion Island (Indian Ocean), supporting two geomagnetic events in the time period 2,2-2,0 Ma. Geophysical Journal International 182, 699-710

Rad, S.D., Allegre, C.J., Louvat, P., 2007. Hidden erosion on volcanic islands. Earth and Planetary Science Letters 262, 109-124

Rancon, J.P., Lerebour, P., Auge, T., 1989. The Grand Brule Exploration Drilling - New Data on the Deep Framework of the Piton-De-La-Fournaise Volcano .1. Lithostratigraphic 
Units and Volcanostructural Implications. Journal of Volcanology and Geothermal Research 36, 113-127

Reading, H.G., Richards, M., 1994. Turbidite Systems in Deep-Water Basin Margins Classified by Grain-Size and Feeder System. AAPG Bulletin 78, 792-822

Reimer, P.J, Reimer, R.W., 2001. A marine reservoir correction database and on-line interface. Radiocarbon 43, 461-463

Robert, R., 2001. Pluviomètrie à l'île de La Réunion: des travaux de J. Defos du Rau (1960) à nos jours. L'information géographique $\mathrm{N}^{\circ} 1,53-59$

Romagnoli, C., Kokelaar, P., Casalbore, D., Chiocci, F.L., 2009. Lateral collapses and active sedimentary processes on the northwestern flank of Stromboli volcano, Italy. Marine Geology 265, 101-119

Rousset, D., Lesquer, A., Bonneville, A., Lenat, J.F., 1989. Complet gravity study of Piton de la Fournaise volcano, Reunion Island. Journal of Volcanology and Geothermal Research 36, 37-52

Saint-Ange, F., 2009. La sédimentation volcaniclastique en contexte de point chaud (île de La Réunion, Océan Indien).PhD Université de La Réunion, France, pp. 279

Saint-Ange, F., Piper, D., Savoye, B., Michon, L., Deplus, C., Bachélery, P., de Voogd, B., Dyment, J., Le Drezen, E., Voisset, M., Le Friant, A., Boudon, G., 2011. A volcaniclastic deep-sea fan off La Réunion Island (Indian Ocean): gradualism versus catastrophism. Geology 39, 271-274

Schneider, J.L., Brunner, C.A., Kuttner, S., 1998. Epiclastic sedimentation during the upper Miocene-lower Pliocene volcanic hiatus of Gran Canaria: evidence from sites 953 and 954, in: Weaver, P.P.E., Schmincke, H.-U., et al., eds., Proc. ODP, Sci. Results, 157: College Station, TX (Ocean Drilling Program) (Ed.), pp. 293-313.

Sisavath, E., Saint-Ange, F., Babonneau, N., Bachelery, P., Deplus, C., de Voogd, B., Savoye, B., 2009. Giant turbidite systems off La Réunion Island - Indian Ocean, EGU 2009. Geophysical Research Abstracts 11: 7105 Vienna.

Smietana, M., Bachèlery, P., Hémond, C., 2010. Heterogeneity in the Mantle Source of La Réunion Island, Goldschmidt 2010. Geochimica et Cosmochimica acta 74 (12 Suppl. 1): A972.

Smith, W.H.F., Sandwell, D.T., 1997. Global sea floor topography from satellite altimetry and ship depth soundings. Science 277, 1956-1962

Société Grenobloise d'Etudes et d'Application Hydrauliques (SOGREAH), 1998. Etude des risques Hydrauliques sur la Rivière Saint-Etienne. Société Grenobloise d'Etudes et d'Application Hydrauliques report 554509 R1, 24 p

Stieltjes, L., Moutou, P., 1988. A statistical and probabilitic study of the historic activity of Piton de la Fournaise, Reunion Island, Indian Ocean. Journal of Volcanology and Geothermal Research 36, 67-86

Wynn, R.B., Kenyon, N.H., Masson, D.G., Stow, D.A.V., Weaver, P.E., 2002. Characterization and recognition of deep-water channel-lobe transition zones. AAPG Bulletin 86, 1441-1462

Wynn, R.B., Masson, D.G., Stow, D.A.V., Weaver, P.P.E., 2000. Turbidity current sediment waves on the submarine slopes of the western Canary Islands. Marine Geology 163, 185198

Wynn, R.B., Stow, D.A.V., 2002. Classification and characterisation of deep-water sediment waves. Marine Geology 192, 7-22

\section{Figure captions}


872 Fig. 1: Predicted bathymetry from Smith and Sandwell (1997) around La Réunion and 873 Mascarene plateau. Overview of the main geological structures of La Réunion Island (insert). 874 The dotted line represents the separation between the two main volcanic edifices.

875

876 Fig. 2: (A) Ship tracks of the three cruises FOREVER (purple line), ERODER1 (blue line) 877 and ERODER2 (green line). (B) Backscatter map compiled from ERODER and FOREVER 878 surveys. White lines correspond to the location of the five fans discovered off La Réunion 879 island: the Cilaos fan, the Mafate fan (1), the Saint-Denis fan (2), the Salazie fan (3) and the 880 Saint-Joseph fan (4). Red and blue dots correspond to sediment cores retrieved in the Cilaos 881 turbidite system. Green dots correspond to the location of the failed coring.

882

Fig. 3: (A) Acoustic backscatter image (based on the FOREVER and ERODER data) of the 884 southwest part of La Réunion showing details of the Cilaos fan. (B) Interpreted shaded relief 885 image of the southwestern flank of La Réunion, compiled from ERODER and FOREVER surveys, showing interpreted subdivisions of the Cilaos fan and the location of Parasound and $3.5 \mathrm{kHz}$ echosounder profiles of figure 8. Canyons are in blue, the proximal fan is outlined in red, the distal fan in yellow, volcanic highs in dark grey, sediment reliefs in light brown, and sediment waves in green.

890

Fig. 4: (A) Swath shaded bathymetry and (B) backscatter image of the canyons area of the 892 Cilaos turbidite system; (C) interpreted image of the canyons area.

893

894 Fig. 5: Slope gradient map with the location of the studied cores. A lithologic log is illustrated 895 for each core, except KERO-18 where only $30 \mathrm{~cm}$ of coarse-grained sands and gravels were collected.

Fig. 6: Location of the three sediment wave fields observed in the Cilaos turbidite system. Profile A-B is topographic profile, profiles C-D and E-F are echosounder profiles.

Fig. 7: (A) Backscatter image and (B) interpreted swath shaded bathymetry of the proximal fan of the Cilaos turbidite system. Red filled dots correspond to sediment cores presented in this paper. 
905 Fig. 8: Parasound and $3.5 \mathrm{kHz}$ echosounder profiles showing the downstream evolution of the 906 fan (profile location in Fig. 3). All these profiles are NW-SE oriented except the SW-NE 907 profile FOR-4a. Grey areas represent the location of volcanic ridges R1, R2, R3 intercepting 908 the profiles.

909

910 Fig. 9: (A) Lithological logs correlated with corresponding echosounder profile; (B) Non911 interpreted and interpreted $3.5 \mathrm{kHz}$ echosounder profiles, showing the succession of the three 912 units U1 (in green), U2 (in grey) and U3 (in blue). For location of each profile see figure 8 913 (black square). (C) Interpretation of the three units U1 (in green), U2 (in grey) and U3 (in 914 blue) on short portion of echosounder profiles, through the three parts of the fan.

916 Fig. 10: (A) Backscatter image and (B) interpreted swath shaded bathymetry of the distal fan 917 of the Cilaos turbidite system. Red filled dots correspond to sediment cores presented in this 918 paper.

919

920 Fig. 11. Grain size diagram, photograph, and X-ray image of few standard turbidite beds of cores KERO-11, KERO-09, KERO-15 and KERO-17.

923 Fig. 12. Schematic diagram illustrating the construction of the Cilaos turbidite system. 
1 Table 1: List of piston cores sampling the Cilaos turbidite system; names are in bold for cores

2 used in this paper.

3

\begin{tabular}{|c|c|c|c|c|c|c|}
\hline Cruises & $\begin{array}{l}\text { Name and } \\
\text { Core Type }\end{array}$ & Lat (S) & Long (E) & $\begin{array}{c}\text { Water } \\
\text { Depth (m) }\end{array}$ & Location & $\begin{array}{l}\text { Length } \\
\text { (m) }\end{array}$ \\
\hline \multirow[t]{2}{*}{ FOREVER } & FOR-C1 & $\mathrm{S} 22^{\circ} 20.95$ & $\mathrm{E} 54^{\circ} 23.33$ & 4074 & $\begin{array}{l}\text { Sedimentary ridge, Central } \\
\text { part of the distal fan }\end{array}$ & 4.51 \\
\hline & FOR-C2 & $\mathrm{S} 21^{\circ} 52.347$ & E5409.39 & 4346 & $\begin{array}{c}\text { Channel floor, Occidental } \\
\text { proximal fan }\end{array}$ & 5,52 \\
\hline \multirow[t]{3}{*}{ ERODER 1} & KERO-01 & $\mathrm{S} 21^{\circ} 50.902$ & $\mathrm{E} 54^{\circ} 11.00$ & 3816 & $\begin{array}{c}\text { Sediment Wave, Up. Cilaos } \\
\text { fan }\end{array}$ & 3,90 \\
\hline & KERO-03 & $\mathrm{S} 21^{\circ} 38.00$ & $\mathrm{E} 54^{\circ} 56.00$ & 3786 & $\begin{array}{c}\text { Channel floor, Occidental } \\
\text { proximal fan }\end{array}$ & 0 \\
\hline & KERO-02 & $\mathrm{S} 21^{\circ} 42.31$ & $\mathrm{E} 54^{\circ} 37.29$ & 3546 & $\begin{array}{c}\text { Channel floor, Up. Cilaos } \\
\text { Fan }\end{array}$ & 3,60 \\
\hline \multirow[t]{11}{*}{ ERODER 2} & KERO-09 & $\mathrm{S} 22^{\circ} 16.347$ & $\mathrm{E} 53^{\circ} 33.060$ & 4460 & $\begin{array}{l}\text { Channel side, western part } \\
\text { of the distal fan }\end{array}$ & 6.27 \\
\hline & KERO-10 & S21 50.902 & $\mathrm{E} 54^{\circ} 11.00$ & 4346 & $\begin{array}{l}\text { Channel floor of the } \\
\text { Occidental proximal fan }\end{array}$ & 0 \\
\hline & KERO-11 & $\mathrm{S} 21^{\circ} 42.31$ & $\mathrm{E} 54^{\circ} 37.29$ & 4164 & $\begin{array}{c}\text { Sediment Wave, Up. Cilaos } \\
\text { Fan }\end{array}$ & 2.65 \\
\hline & KERO-12 & $\mathrm{S} 22^{\circ} 23.550$ & E5332.752 & 4461 & $\begin{array}{l}\text { Channel side, western part } \\
\text { of the distal fan }\end{array}$ & 6.40 \\
\hline & KERO-13 & $\mathrm{S} 22^{\circ} 25.98$ & $\mathrm{E} 53^{\circ} 36.36$ & 4407 & $\begin{array}{l}\text { Channel floor, western part } \\
\text { of the distal fan }\end{array}$ & 0.98 \\
\hline & KERO-14 & $\mathrm{S} 22^{\circ} 20.50$ & $\mathrm{E} 53^{\circ} 40.88$ & 4439 & $\begin{array}{l}\text { Channel floor, western part } \\
\text { of the distal fan }\end{array}$ & 3.47 \\
\hline & KERO-15 & $\mathrm{S} 22^{\circ} 17.39$ & $\mathrm{E} 52^{\circ} 56.10$ & 4529 & Distal part, Cilaos distal fan & 6.68 \\
\hline & KERO-16 & $\mathrm{S} 22^{\circ} 19.51$ & $\mathrm{E} 54^{\circ} 07.78$ & 4340 & $\begin{array}{c}\text { Channel side, Central part } \\
\text { of the distal fan }\end{array}$ & 4.95 \\
\hline & KERO-17 & $\mathrm{S} 22^{\circ} 22.540$ & $\mathrm{E} 54^{\circ} 12.267$ & 4353 & $\begin{array}{l}\text { Channel floor, Central part } \\
\text { of the distal fan }\end{array}$ & 5.34 \\
\hline & KERO-18 & $\mathrm{S} 21^{\circ} 22.00$ & $\mathrm{E} 55^{\circ} 15.22$ & 2056 & Canyon area & $\begin{array}{l}\text { Sample } \\
(\sim 0,3)\end{array}$ \\
\hline & KERO-19 & $\mathrm{S} 21^{\circ} 22.873$ & E55ำ13.669 & 2221 & Canyon area & 0 \\
\hline
\end{tabular}

4 
1 Table 2: Radiocarbon dates from cores KERO-09 and KERO-16

2

\begin{tabular}{|c|c|c|c|c|c|c|}
\hline \multirow{2}{*}{$\begin{array}{c}\text { Laboratory } \\
\text { number }\end{array}$} & \multirow{2}{*}{ Core } & \multirow{2}{*}{$\frac{\text { Depth }}{\text { (cm bsf) }}$} & \multirow{2}{*}{$\begin{array}{l}\text { AMS 14C } \\
\text { age (yr) }\end{array}$} & \multirow{2}{*}{$\begin{array}{l}\text { AMS 14C } \\
\text { age } \\
(-400 y r)\end{array}$} & \multirow{2}{*}{ Error yr } & \multirow{2}{*}{$\frac{\text { Calendar Age }}{\text { (cal yr BP) }}$} \\
\hline & & & & & & \\
\hline Poz-35177 & KERO-09 & 3 & 11840 & 11440 & 60 & 13302 \\
\hline Poz-35180 & KERO-09 & 69 & 38500 & 38100 & 600 & 42587 \\
\hline SacA 21882 & KERO-16 & 60,5 & 11610 & 11210 & 35 & 13118 \\
\hline SacA 21883 & KERO-16 & 122,5 & 29660 & 29260 & 160 & 34422 \\
\hline
\end{tabular}

3 


\section{Figure 1}

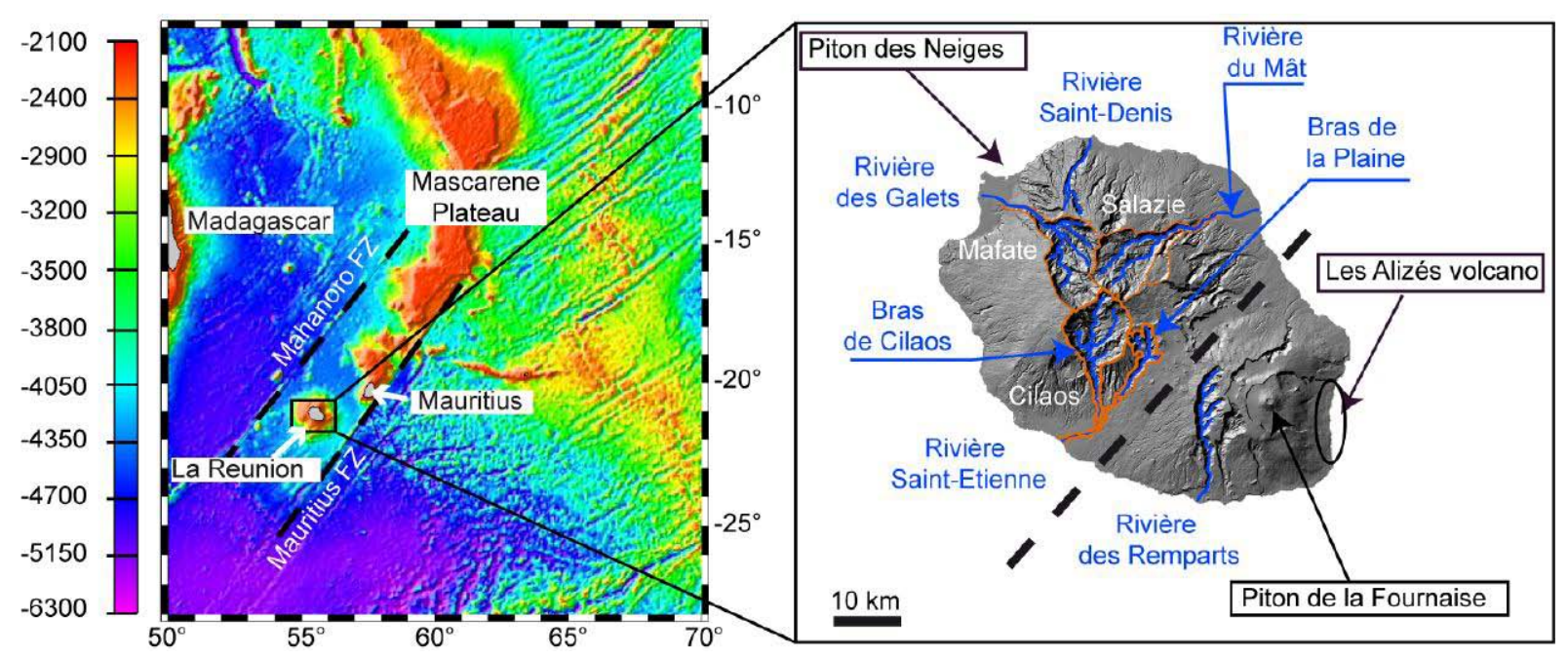


Figure 2

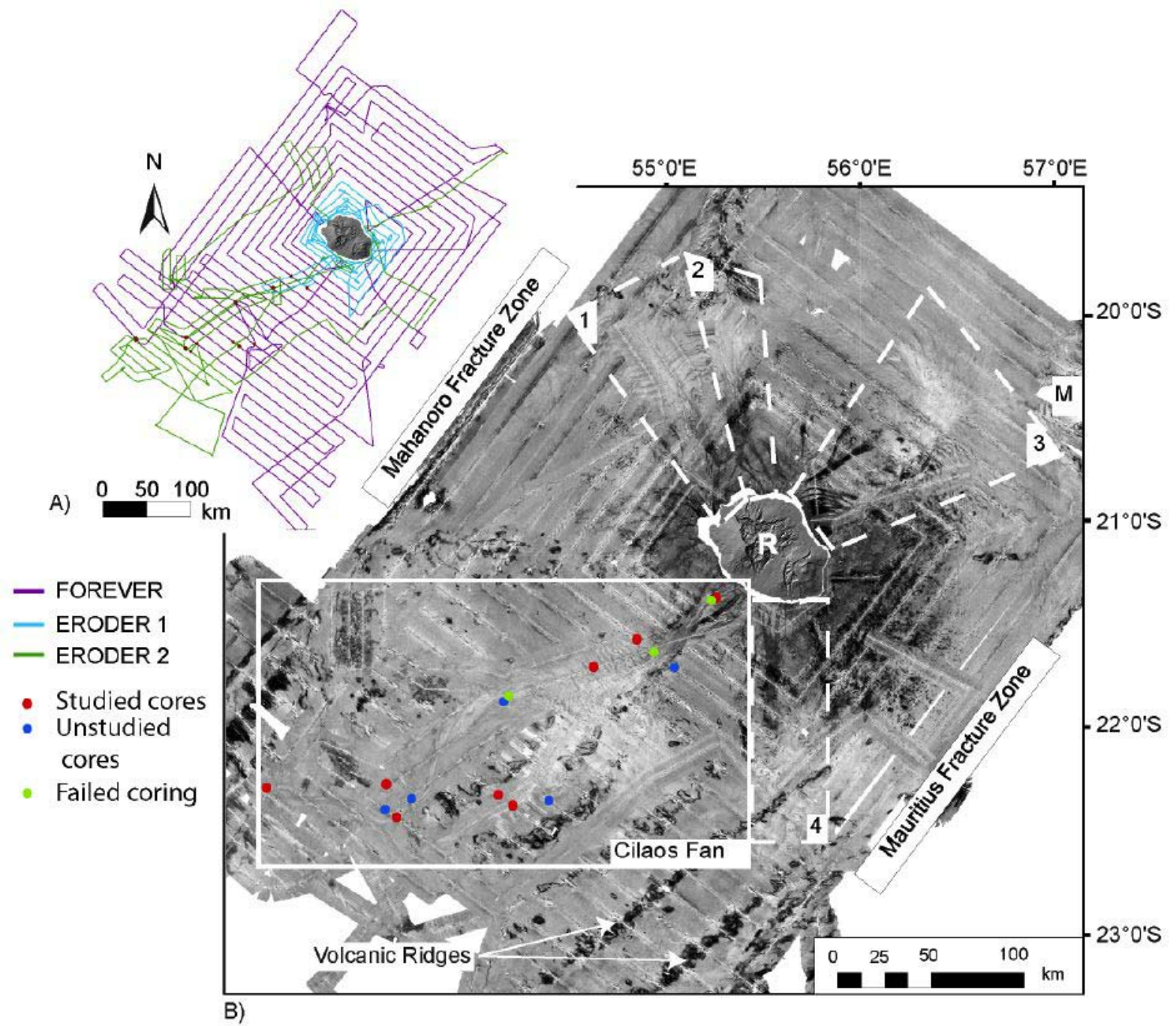


Figure 3
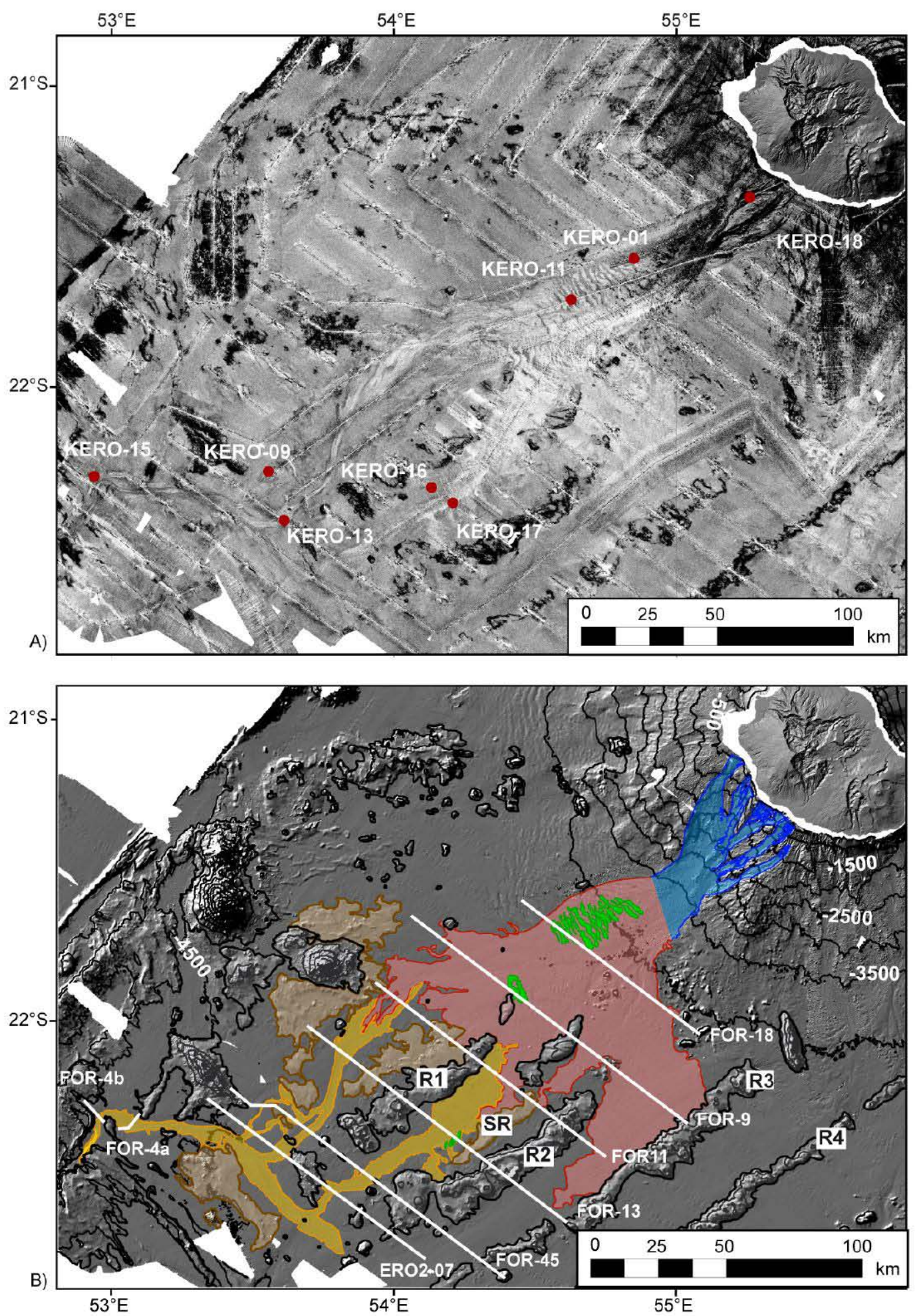
Figure 4
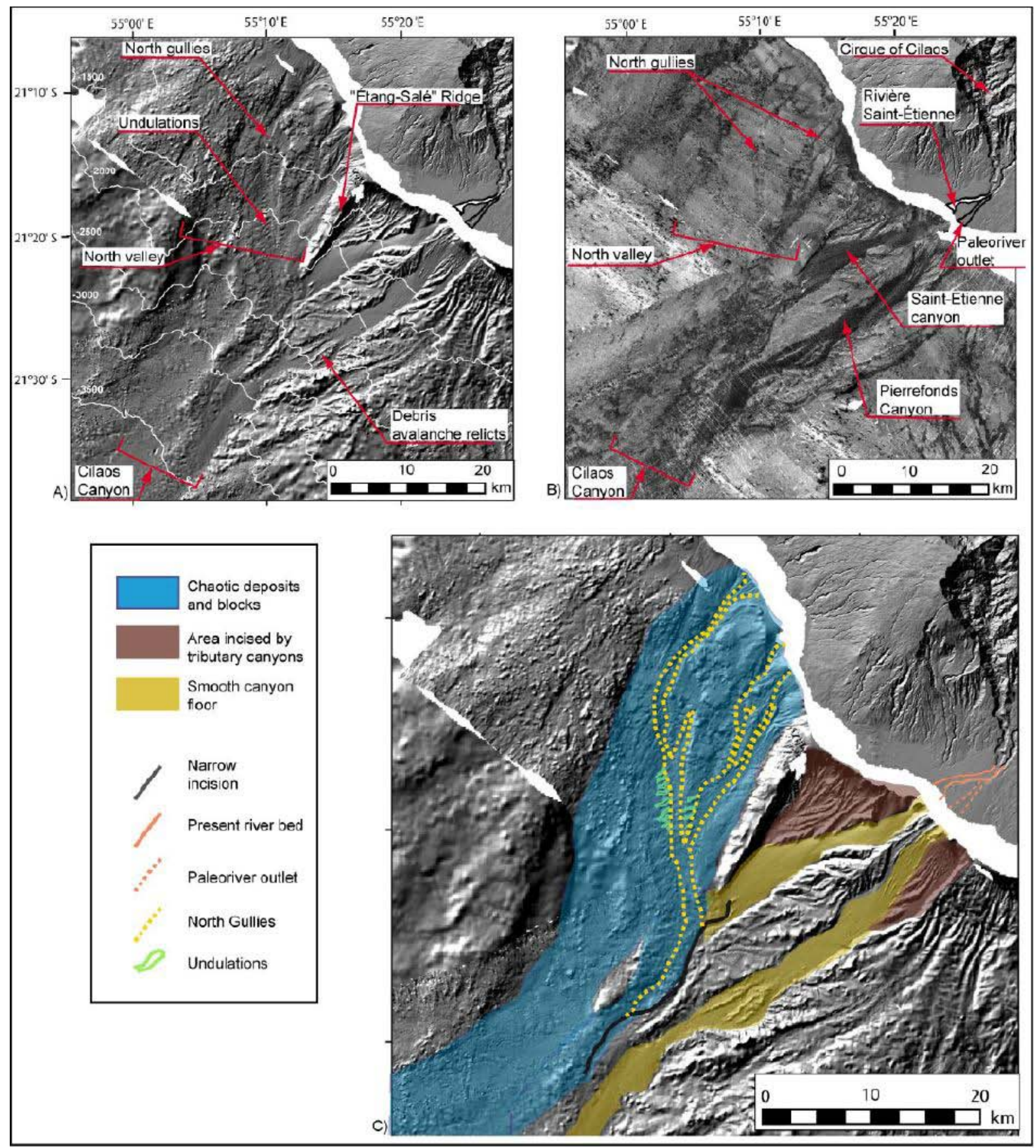
Figure 5
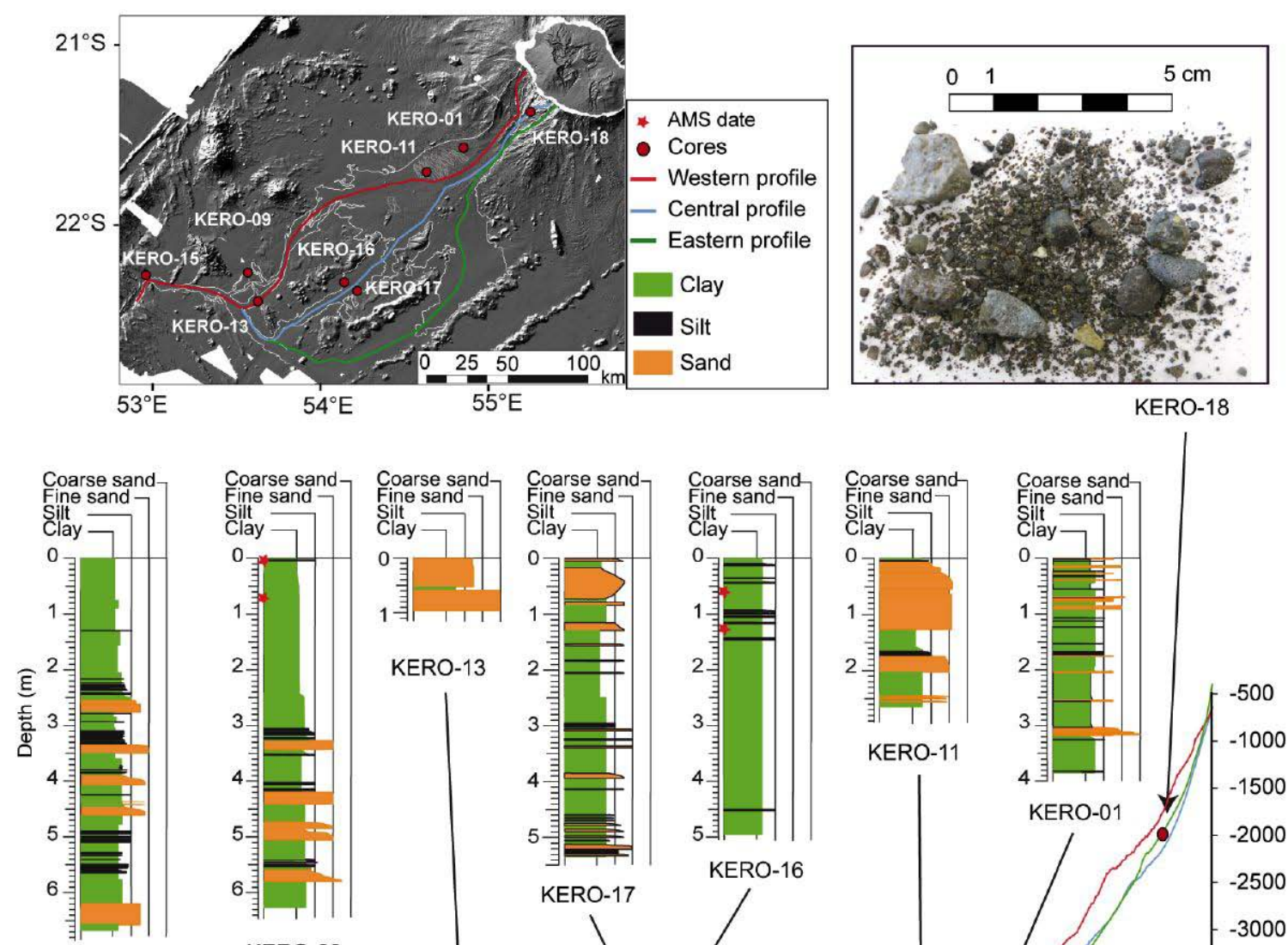

Coarse sand
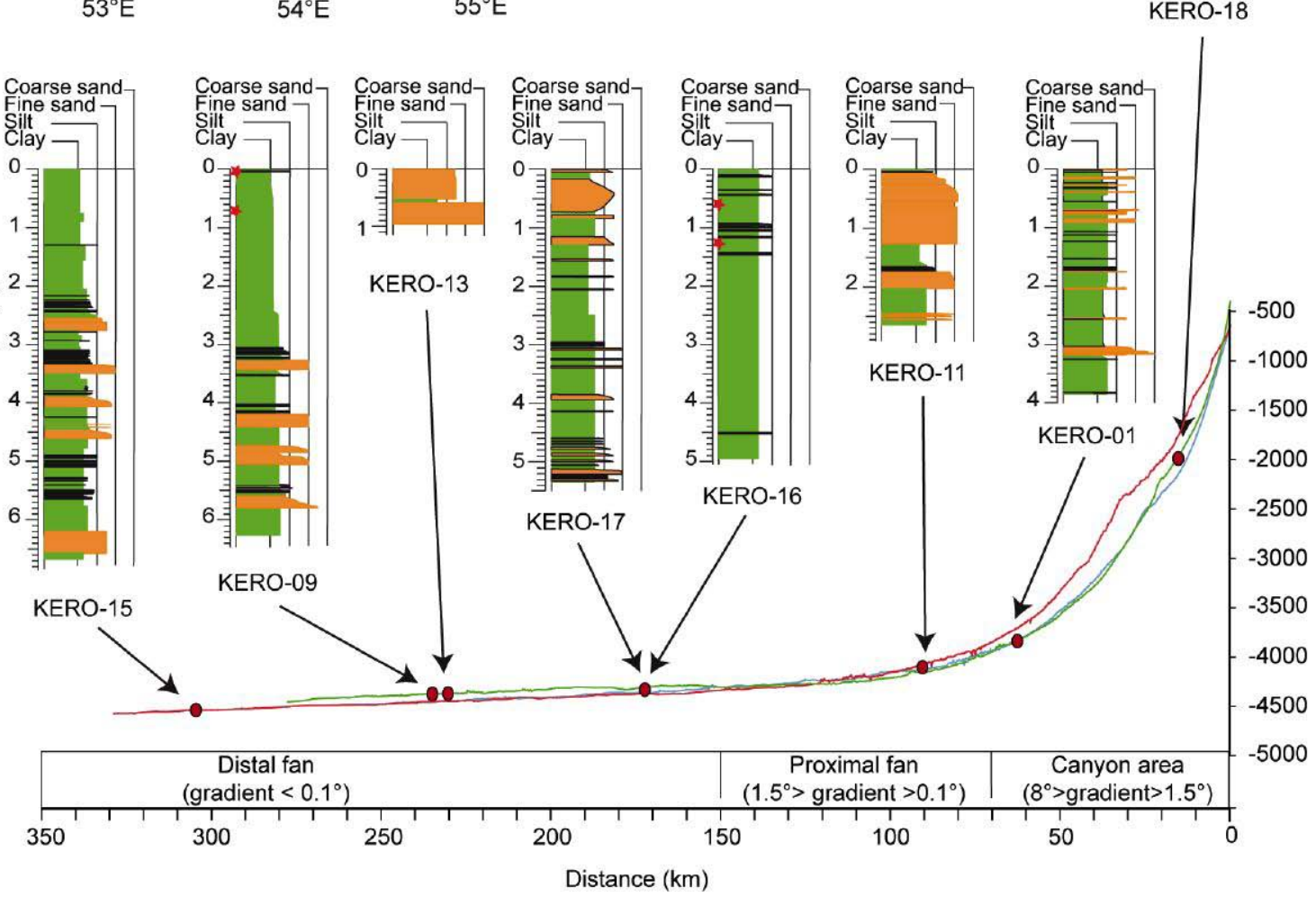
Figure 6

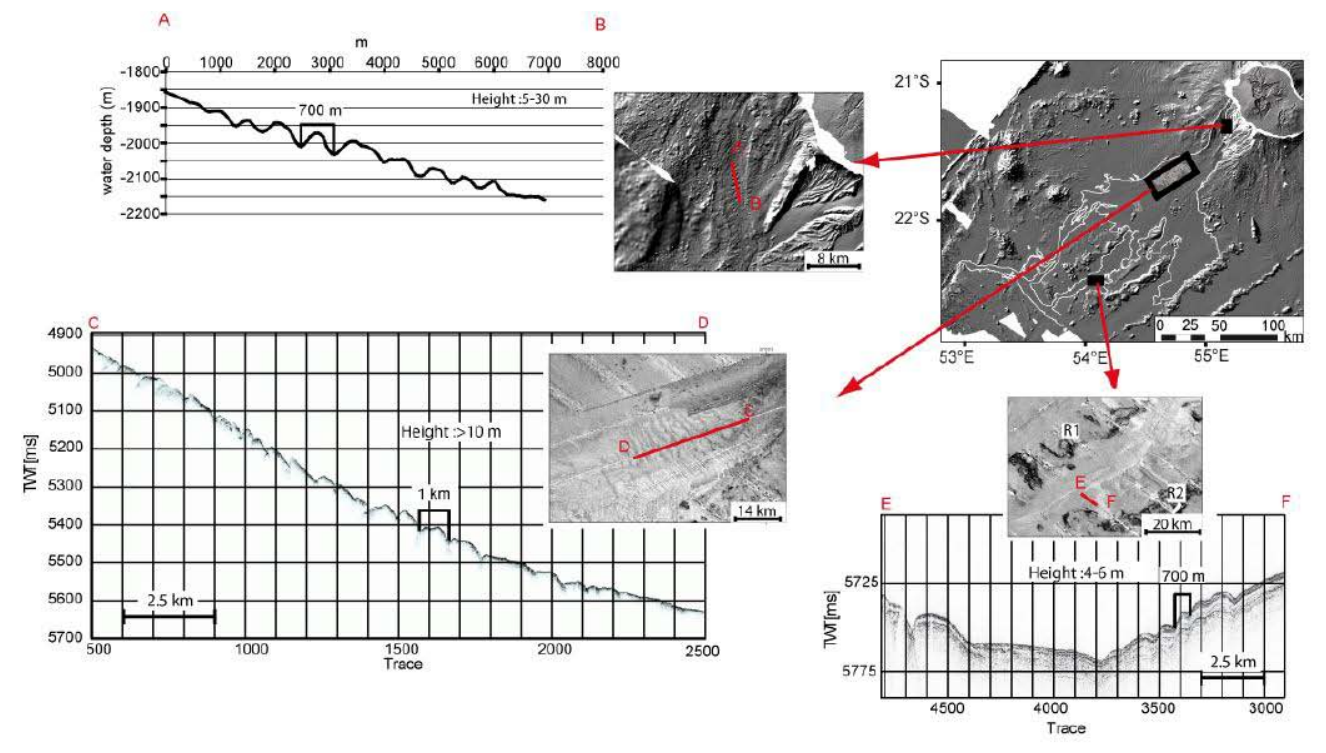


Figure 7
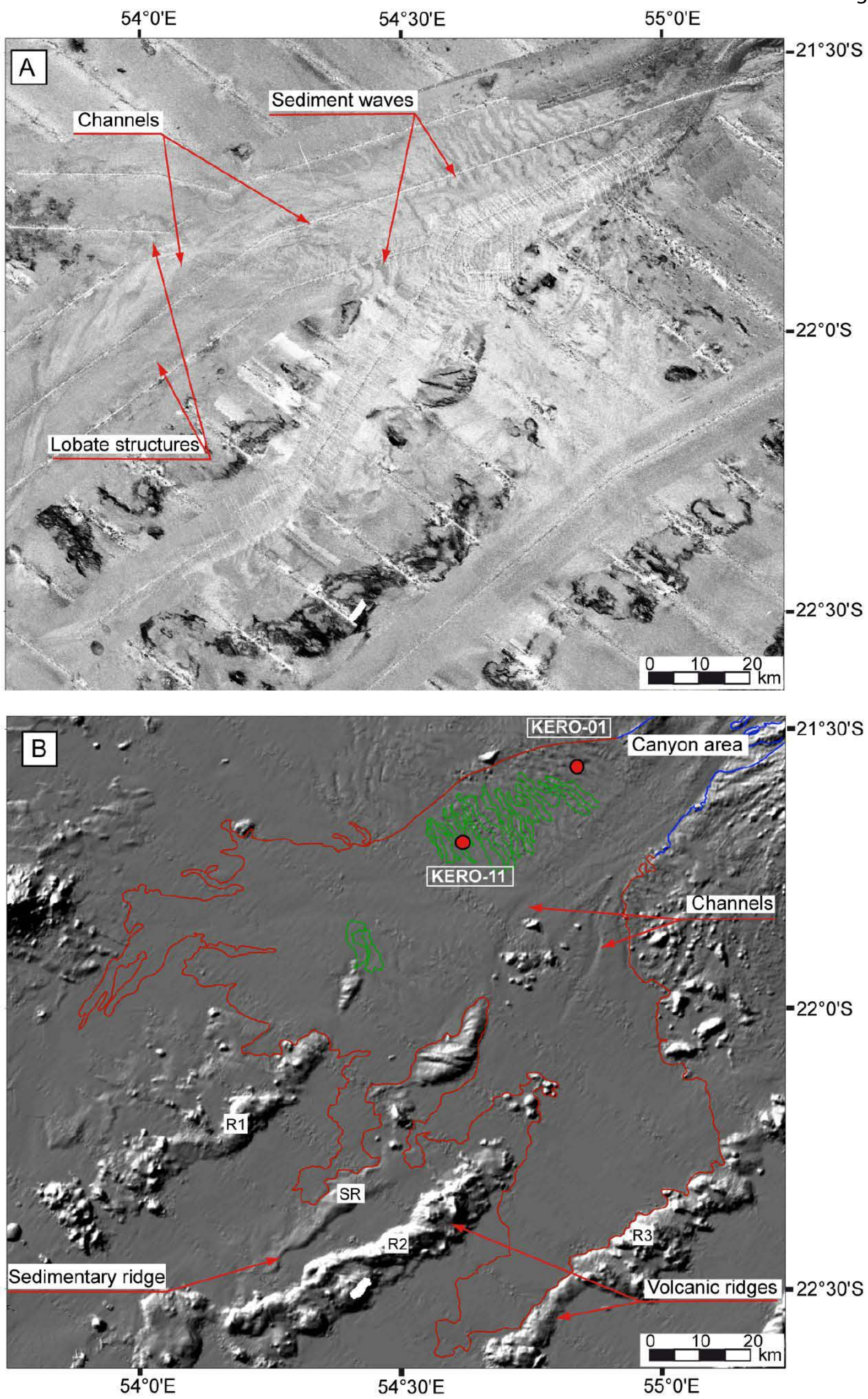
Figure 8

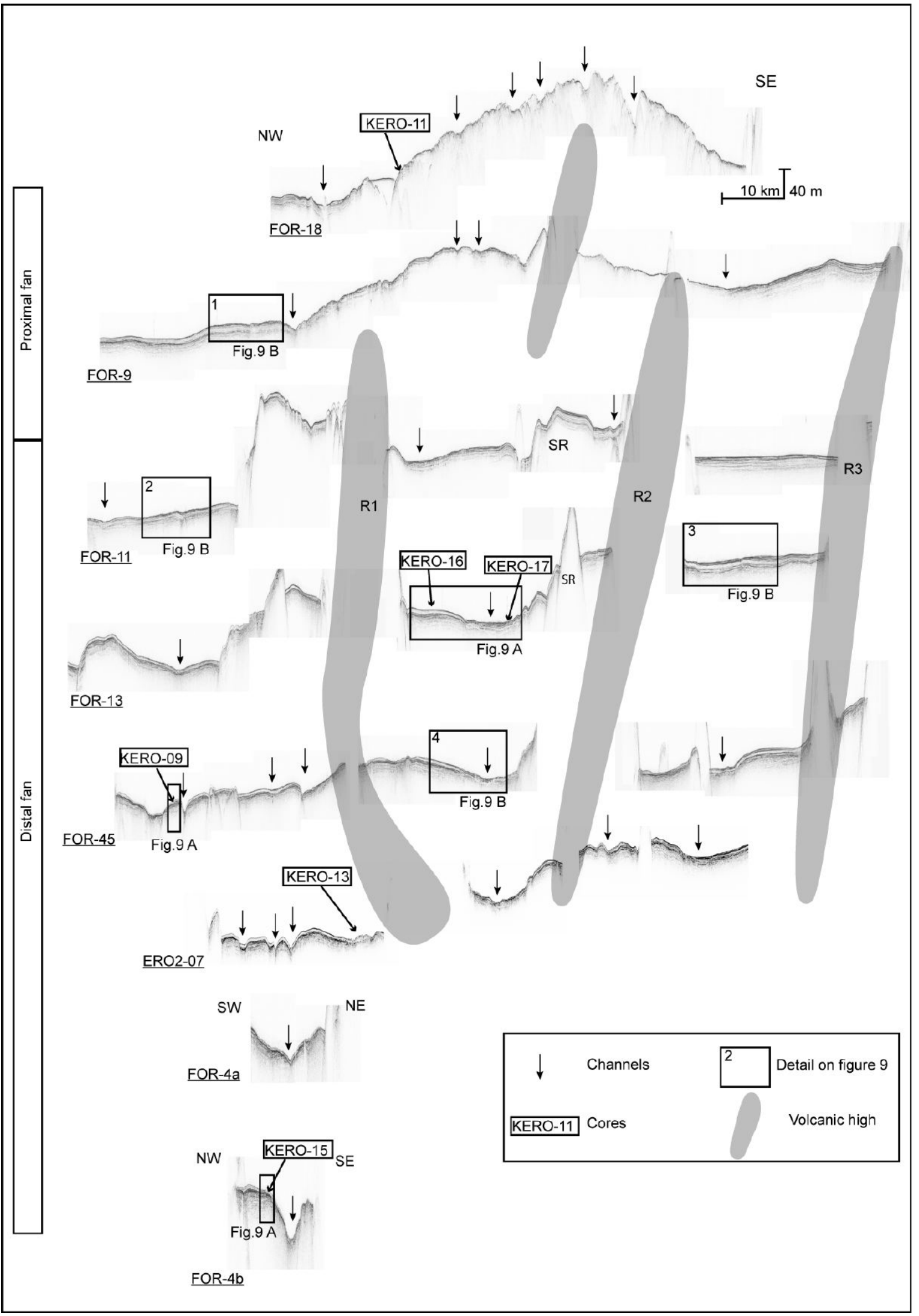




\section{Figure 9}

\section{A - Correlation between echosounder profiles and cores}
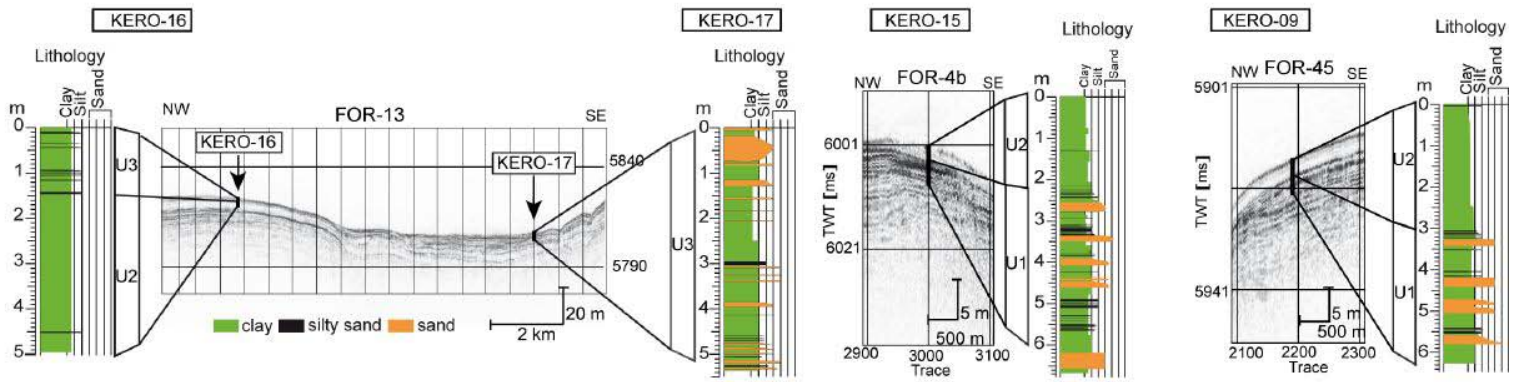

B - Interpolation of the interpretation of the three acoustic units on profiles
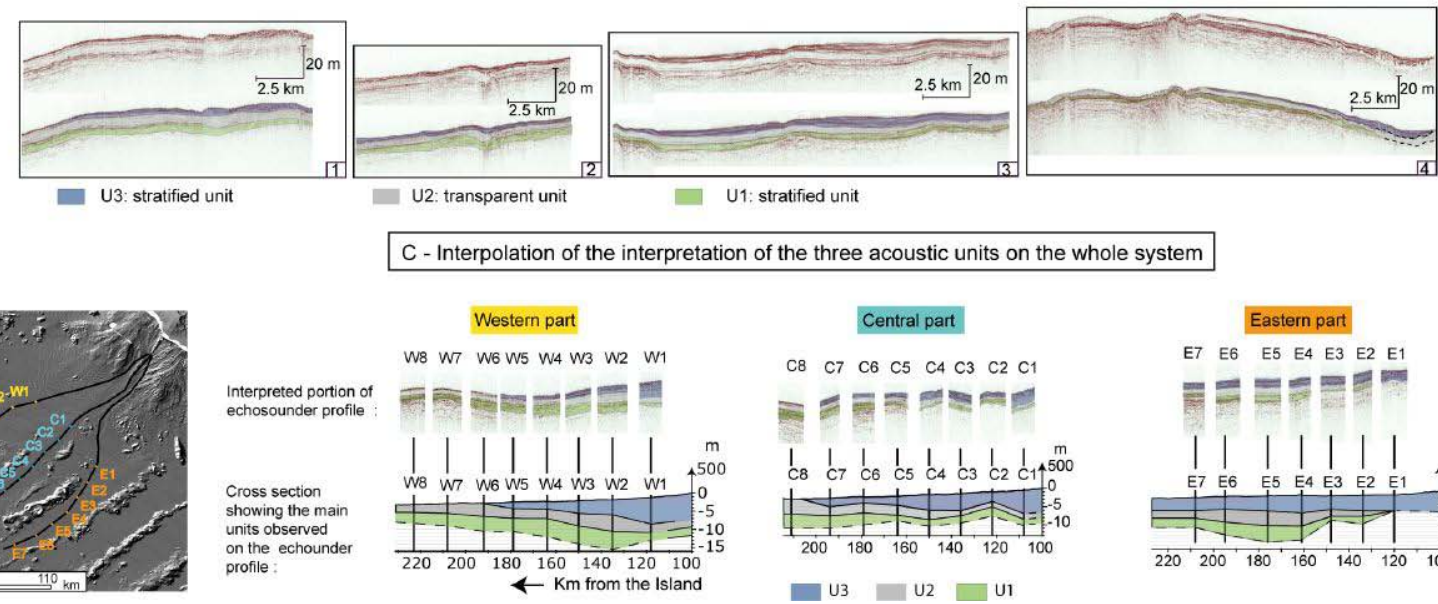

U1: stratified unit

U3:
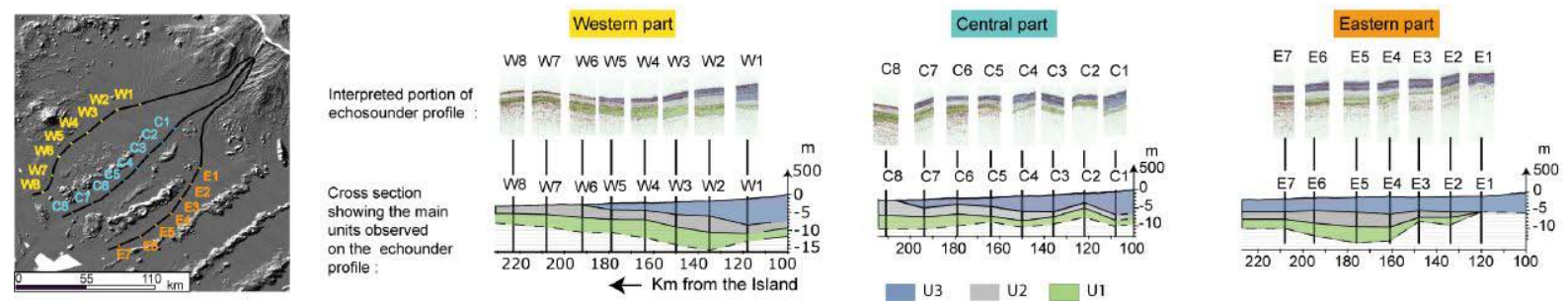
Figure 10
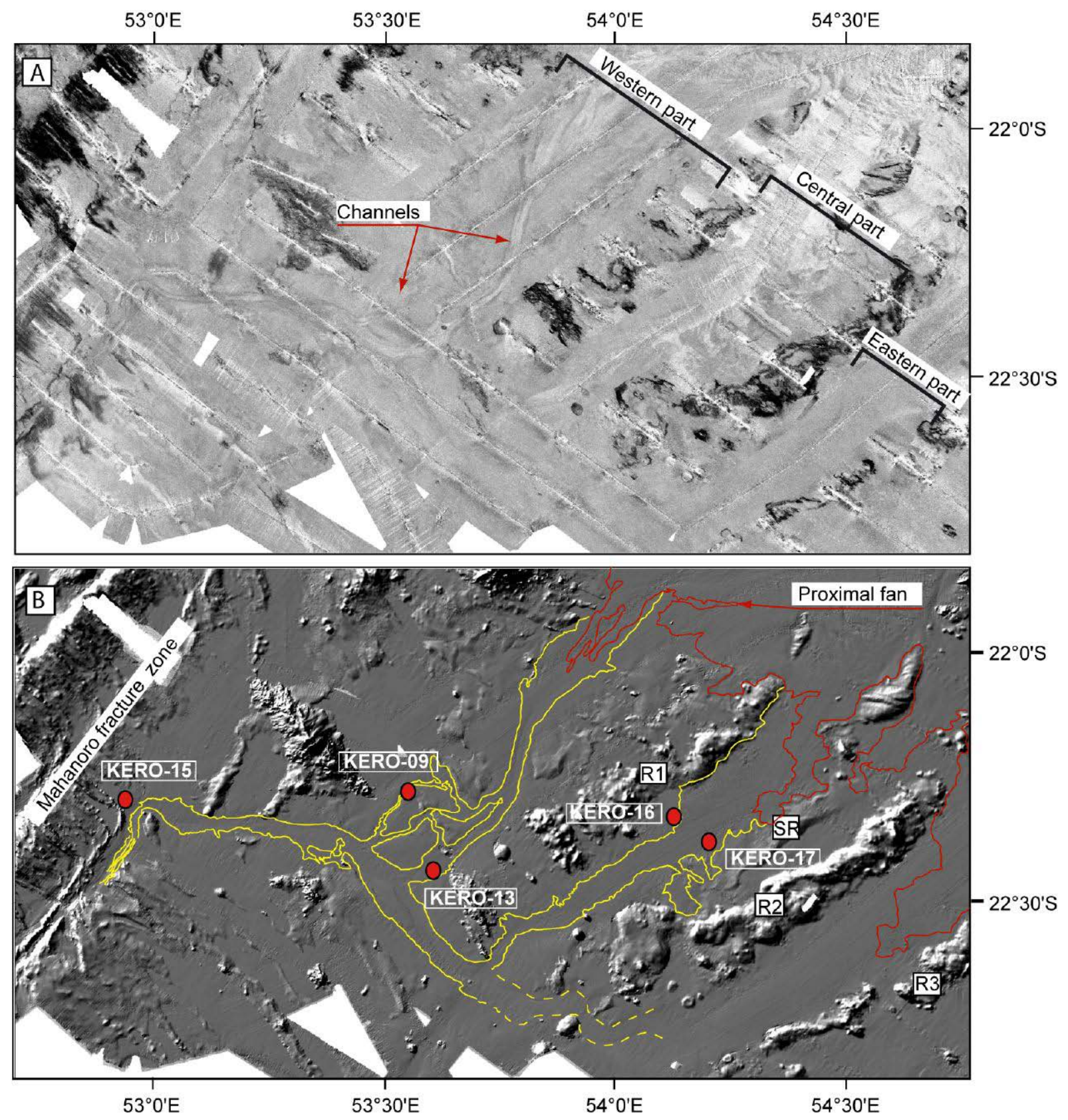
Figure 11

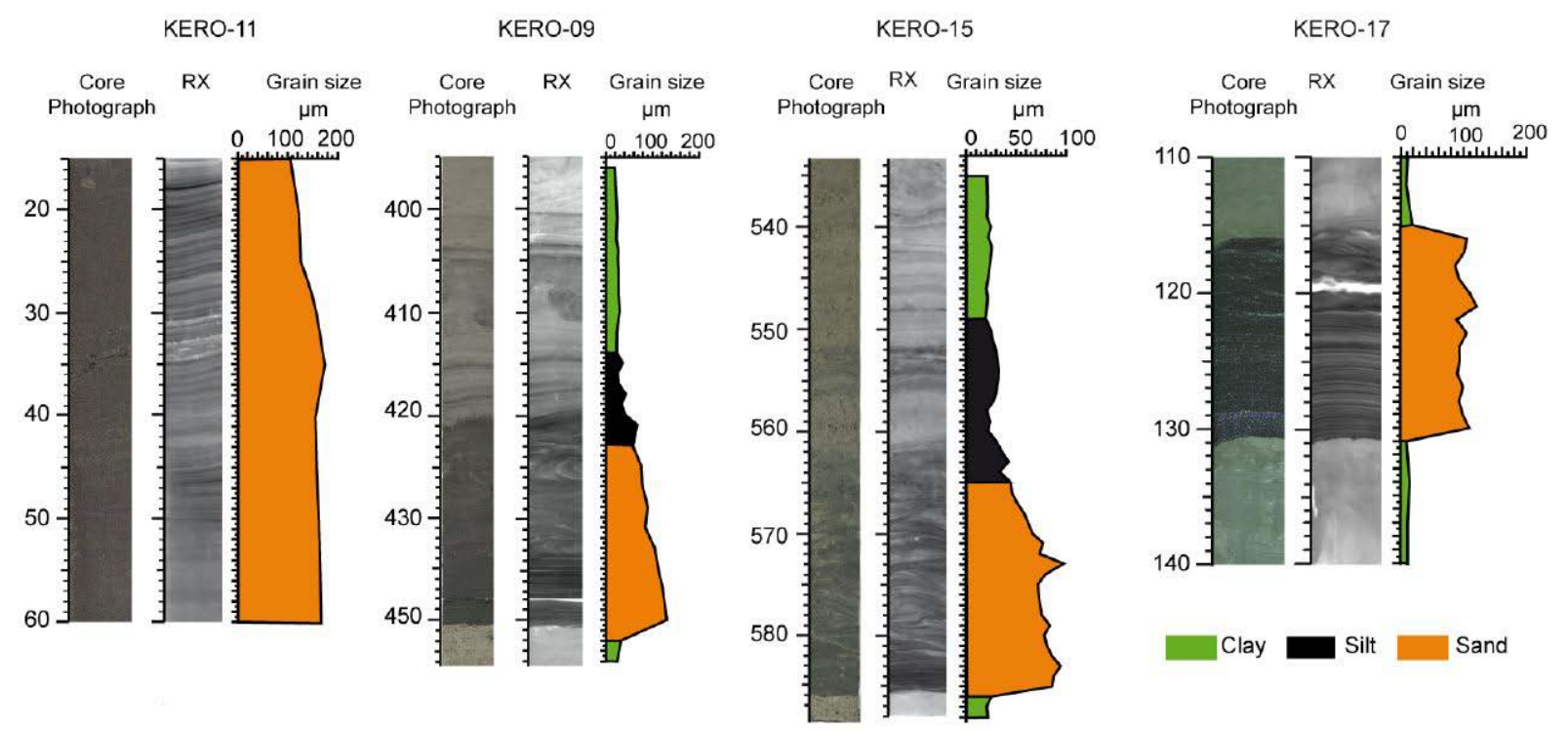




\section{Figure 12}

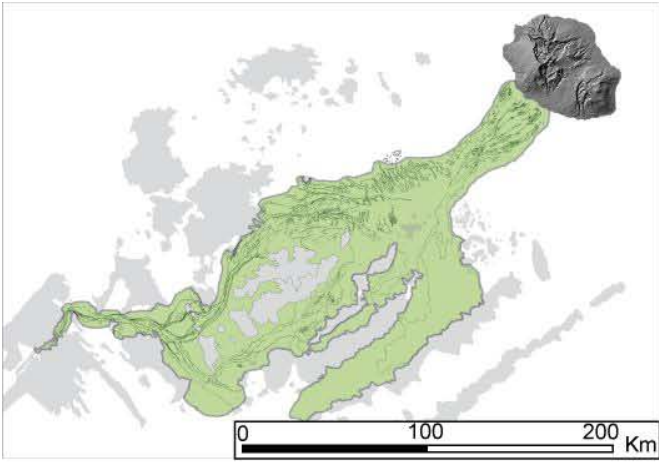

T1: Old stage : important turbidites spreading over the entire fan and all the distal locations

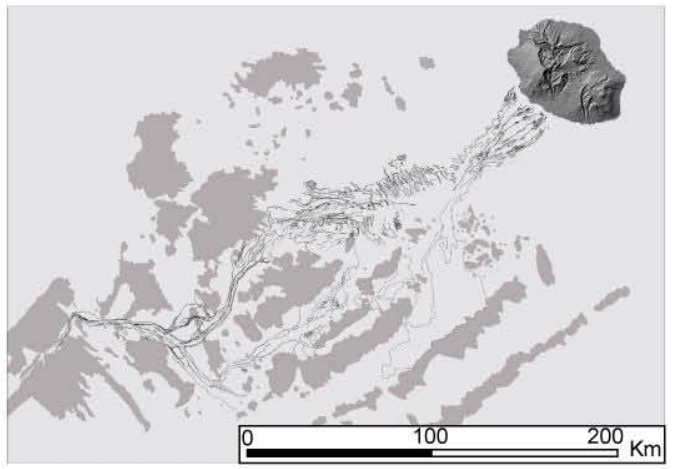

T2: Interruption in the turbidite activity of the system characterized in the cores by a thick layer of clay

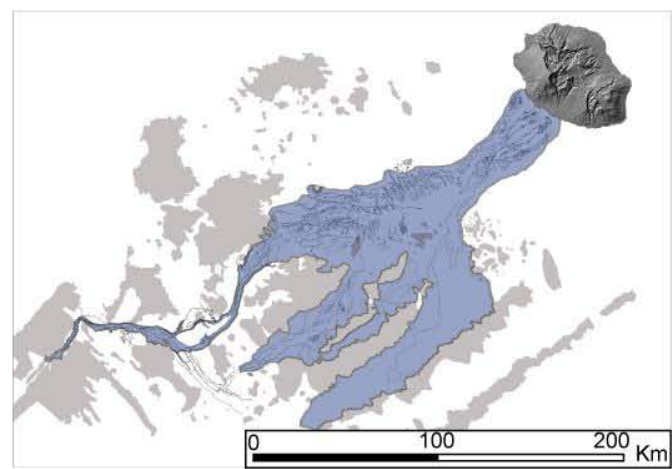

T3: Present activity limited to the eastern, central and proximal part of the western system and to the channel floors. 